\title{
Lider-Üye Etkileşiminin İş Tatmini ve İşten Ayrılma Niyetine Etkisinde Psikolojik Sermayenin Düzenleyici Rolü ${ }^{1}$
}

\author{
DOI: 10.26466/opus.918842
}

\author{
* \\ Yasemin Büyükkaymakc1 ${ }^{*}$ - Mustafa Sundu** \\ * BNP Paribas Finansal Kiralama A.Ş., İstanbul/Türkiye \\ E-Posta: yasemingol@icloud.com \\ ORCID: $\quad$ 0000-0002-2204-8502 \\ ** Dr. Öğr. Üyesi, İstinye Üniversitesi, İisBF, İstanbul/Türkiye \\ E-Posta: mustafasundu@gmail.com \\ ORCID: $\underline{0000-0003-4168-9273}$
}

\section{Öz}

Bu araştırma ile lider-üye etkileşiminin iş tatmini ve işten ayrılma niyetine etkisi ile oluşan etkide psikolojik sermayenin düzenleyici rolü olup olmadığının incelenmesi amaçlanmıştır. Çalışmada nicel bir saha araştırması yapılmıştır. Geçerli ölçekler kullanılarak hazırlanmış olan anket, yüksek lisans tez çalışması esnasında 2019 yılında toplanmıştır. Anketin 45 adeti basıl form olarak, ilgililer tek tek bilgilendirilerek doldurulması sağlanmıştır. 237 adet anket ise SurveyMonkey ve Google/Docs uygulaması ile online olarak doldurulmuştur. Tüm sonuçlar SPSS programı kullanılarak analiz edilmiş ve yorumlanmıştır. Yapılan inceleme ve çalışmalar neticesinde lider üye etkileşiminin pozitif ve negatif olarak işten ayrnlma niyeti ve iş tatmini üzerinde etkili olduğu ortaya çıkmıştır. Lider üye etkileşiminin işten ayrılma niyetine etkisinde, üyenin psikolojik sermayesinin düzenleyici etkisinin olduğu, ancak Lider üye etkileşiminin iş tatmine etkisinde ise psikolojik sermayenin düzenleyici etkisinin olmadığı görülmüştür. Bu nedenle çalışanın psikolojik sermaye düzeyinin ölçülmesinin örgütler için anlaml sonuçlarının olacağ̀ önerilmiştir. Analiz sonuçları incelendiğinde lider üye etkileşiminin örgüt için önemli iki unsur olan işten ayrlma niyeti ve iş tatmini üzerinde etkili olduğu görülmüştür. Ayrıca bu iki değişken arasındaki ilişkide çalışanların psikolojik sermaye düzeylerinin etkili olduğu ortaya çıkmıştır. Personellerin bu kıstas göz önüne alınarak seçilmesi organizasyonun etkinliğini artıracak ve insan kaynakları yönetimi politikalarına katkı să̆layacaktır.

Anahtar Kelimeler: Lider-Üye Etkileşimi, İş Tatmini, İşten Ayrılma Niyeti, Psikolojik Sermaye, $\dot{I} K$.

\footnotetext{
${ }^{1}$ Bu çalışma Dr. Öğr. Üyesi Mustafa SUNDU'nun danışmanlığında, Yasemin Büyükkaymakcı tarafından yazılan "Lider Üye Etkileşiminin Iş Tatmini ve Iş̧ten Ayrılma Niyetine Etkisinde Psikolojik Sermayenin Düzenleyici Rolü" başlıklı yüksek lisans tezinden üretilmiştir.
} 


\title{
The Moderator Role of the Psychological Capital in the Effect of Leader-Member Exchange on Job Satisfaction and Intention to Leave
}

*

\begin{abstract}
This research aims to examine the effect of leader-member interaction on intention to quit and job satisfaction, and the role of psychological capital in this effect. The questionnaire, which was prepared using valid scales, was collected in 2019 during the master's thesis study. 45 of the questionnaire is in printed form, and the relevant people are informed one by one and filled out. 237 questionnaires were filled online via SurveyMonkey and Google/Docs. All results were analyzed and interpreted using SPSS program. As a result of the analyses and studies, it was revealed that the interaction between the leader and the members positively and negatively has an effect on the intention to quit and job satisfactionIt has been observed that the psychological capital of the member has a moderator role on the effect of leader member exchange on intention to leave, but psychological capital has no moderator role on the effect of leader member exchange on job satisfaction. For this reason, it suggested that measuring the psychological capital level of the employee will have significant results for organizations. When the results of analysis are examined, it is seen that leader member exchange has an effect on intention to leave and job satisfaction, which are two important elements for the organization. In addition, it has been revealed that the psychological capital levels of the employees are effective in the relationship between these two variables. Selecting the personnel considering this criterion will increase the efficiency of the organization and contribute to the human resources management policies.
\end{abstract}

Key Words: Leader-Member Exchange, Job Satisfaction, Intention to Leave, Psychological Capital, $H R$. 


\section{Giriş}

Günümüzde gelişen teknoloji, globalleşme, artan ve çeşitlenen iletişim araçları teknikleri, örgütler için en temel unsur olan insanların birçok yönden değişmesine neden olmaktadır. Çalışma hayatının da insan için önemi artmaya başladıkça, çalışma hayatından beklentiler yükselmeye ve kişinin kendini geliştirme, gerçekleştirmesi için var olduğu bir sosyal ortam olarak algılanmaya başlamıştır. $\mathrm{Bu}$ çalışmada lider-üye etkileşiminin işten ayrılma niyetine ve iş tatminine etkisi incelenecek olup bu etkide psikolojik sermayenin düzenleyici rolü araştırılacaktır. İşten ayrılma niyeti ve iş tatmini hem pozitif hem negatif anlamda lider-üye etkileşiminden ne ölçüde etkilenmekte ve bu etki üzerinde psikolojik sermayenin düzenleyici rolünün ne düzeyde olduğu yapılan araştırmamızda incelenmiş ve bulgular değerlendirilmiştir. Çalışma ile insan kaynakları yönetimde, güncel politikaların belirlenmesi ve liderlik süreçlerinin takibinde belirleyici olacağı düşünülmekle birlikte, çalışanların psikolojik sermayelerinin işe alım süreçleri ve kariyerleri boyunca takip edilebilmesinin önemine ilişkin yön verici olması beklenmektedir.

\section{Literatür}

Lider, grup üyelerince maruz kalınan fakat, net bir şekilde ortaya konmamış ortak düşünce ve hedeflerin kabul edilmesini amaç olarak belirlemiş ve grup üyelerinin sahip oldukları olumlu yönlerin bu amaç çerçevesinde hayata geçiren kişidir (Eren, 1991). Liderlik süreci ise Werner tarafından; belirli koşullar altında grup üyelerinin ortak amaçlara ulaşmak için gönüllü bir şekilde harekete geçmesini sağlayan, onlara yardım eden, tecrübelerini paylaşan, ortaya konulan liderlik şeklinden memnun kalmalarını sağlayan etkileme süreci şeklinde tanımlanmıştır (Werner, 1993). Liderlik kavramı üzerine yapılan çalışmalar yoğunlaştıkça lider ile üye arasındaki ilişkide çokça araştırma konusu olmuştur. Yapılan çalışmalar neticesinde görülmektedir ki geleneksel liderlik yaklaşımları, lider ile astlar arasındaki ilişkilerde yetersiz kalmaktadır. Bununla beraber geleneksel bir bakış açısı olan duyguların ve psikolojinin iş hayatında yeri olmadığ kabulü günümüzde etkisini yitirmektedir. 
Lider-üye etkileşimi kavramı, liderin her bir üyeye eşit bir şekilde tavır takındığ 1 ve bu şekilde muamelede bulunduğu iddia olunan genel geçer liderlik anlayışının tersine, liderin her bir üyeye başka içerikte yaklaşım geliştirdiği anlayışından yola çıkarak meydana gelmiştir. (Martin ve diğg., 2005). Lider-üye etkileşim (leader-member exchange) kavramı, liderlik sürecini etkileşimsel bir alan içerisinde incelemeye almaktadır (Liden ve Maslyn, 1998; Scandura ve diğ., 1986). Lider-üye etkileşim kavramı ile alakalı olarak yapılan inleme ve yazınlarda liderin kendilerine tabi olan ekip çalışanlarının her birisiyle veya yüksek nitelikde ve farklı biçimlerde etkileşim oluşturduğu tespit edilmektedir. Bu bağlamda ilişkinin içerinin takım için işten aldığı tatmin, örgütüne bağlılığı, çalışma performansı, örgütte kalma süresi gibi sonuçlar üzerinde doğrudan etkisi olduğu ileri sürülmektedir. Lider ve takım arasındaki bağın şeklini tayin eden bir tek boyutun yeterli olmadığını ortaya koyan araştırmacılar lider ve takım içerisindeki bu iletişim boyutlarını ortaya koyabilmek çok boyutlu yaklaşımlar oluşturmuşlardır (Arslantaş, 2007). Lider-üye etkileşimi yaklaşımıda lider ile üye arasındaki ilişkileri dört boyut olarak ele almaktadır. Bu boyutlar; etki, katkı, vefakarlık ve profesyyonellikdir.

Etki boyutu ile ilgili olarak Dienesch ve Liden (1986) tarafından; "Etkileşimin tarafları arasında, iş veya profesyonel değerlerden daha çok kişiler arası çekiciliğe dayanan karşılıklı ilişki" şeklinde tanımlama yapılmıştır. Bu doğrultuda, sadece iş odaklı bir etkileşim söz konusu olduğunda, etki boyutu önemli olmayacaktır. Lider ile üye her iki yönden de duyguya dayalı bir iletişim oluşturur, aralarında arkadaşça ve sıcak bir ortam oluşur. Böyle bir ortamda üyeler liderlerinden sadece iş ile ilgili değil, iş dişında oluşan sorunlar için de destek beklentisinde olurlar (Greguras ve Ford, 2006).

Katkı boyutu ise, "İlişkinin taraflarının ortak iş amaçları için ortaya koydukları çabaların algılanan miktar ve kalitesi" olarak tanımlanmıştır (Dienesch ve Liden, 1986). Özel ilgi gerektiren işleri tamamlama firsatı bulan üyeler, etkileşimi daha fazla ilerletme şansına sahip olacaklardır (Liden ve Maslyn, 1998).

Vefakârlık boyutu lider ve ekibinin karşılıklı vefa gösterme seviyesi olarak ifade edilebilir. Liderler takım ile aynı amaçlar doğrultusunda daha yüksek çaba gösteren üyelerini daha fazla koruyacak, üyeler ise bu durumda daha fazla gayret göstereceklerdir (Liden ve Maslyn, 1998). 
Profesyonel saygı boyutunda lider ile üyeler karşılıklı olarak iş ile ilgili uzmanlık, bilgi ve becerilerine yönelik etkileşim oluşturmaktadırlar. Liden ve Maslyn bu boyutu "ilişkinin taraflarından her birinin örgüt içinde ya da dışında sahip oldukları saygınlık derecesine yönelik algı" olarak ifade etmişlerdir (Liden ve Masly, 1998).

İş tatmini kavramının da çalışan ve örgüt açısından önemi büyüktür. İş tatmini; çalışanın işine yönelik hisleri ile ilgili ve birden fazla faktöre bağlı bir kavram olarak ifade edilebilmektedir. İş tatmini, çalışanın faaliyetlerine yönelik gösterdikleri duygusal tepki olarak belirtilmiştir (Çelik Keleş, 2006). İş tatminine ve iş tatminsizliğine sebep olabilecek tüm etmenler birey tarafından deneyimlenir ve neticede tek bir duygu hâkim olur. Bu nedenle işe karşı ya tatmin duygusu beslenir ya da işe karşı bir tatminsizlik duygusu oluşur yani başka bir ifade ile iş tatmini sadece pozitif ve negatif olabilir ancak her iki durumda da kendi içerisinde farklı yoğunluklarda hissedilebilir (Taşlıyan, 2007). İş tatmini hem bireysel hem de örgütsel açıdan önemlidir. Bireysel olarak irdelendiğinde, çalışanlar zamanlarının oldukça fazla bir kısmını işte ve işe geliş gidiş sürecinde geçirmektedir. Bu nedenle çalışanlar çalıştıkları süre zarfında iş yerinde her türlü ihtiyaç ve taleplerinin giderilmesini arzulamaktadırlar. İş tatmini hissedilmediği zaman çalışanın verimi düşecek, kayıtsız davranışlar izlenecek, işin yavaşlatıldığı gözlemlene bilecek ve işten ayrılma gibi örgütü olumsuz yönde etkileyecek sonuçlar ortaya çıkabilecektir (Sat, 2011). İş tatmin düzeyi diğerlerine göre daha az olan çalışanların diğer çalışanların motivasyonunu düşürdüğünü, enerjisi ve performans kayıplarına neden olduğu söylenebilir. Bu da göstermektedir ki örgüt içerisinde iş tatmini yüksek olan çalışanlarının düşük olanlara oranla daha çok olması örgütün verimi için büyük ölçüde önem taşımaktadır (Elmas, 2017). Bu bağlamda bir örgütte çalışanlar iş tatmini hissetmediğinde örgüt için fazladan maliyetler oluşmakta, çalışan devri ve rotasyonu artmakta buna bağlı olarak işe yeni başlayan maliyetleri yükselmekte ve bu süreçler oluşan iş ve emek kaybını artırmaktadır. İş tatmini olgusu örgüt içerisinde çalışanların genelinde yüksek olarak izlendiğinde ise örgüt bağl1lı̆g verimliliği artmaktadır (Sunar, 2016). İş tatmininiyle ilşkili unsurlar bireysel faktörler ile örgütsel faktörler olmak üzere iki grupta toplanmaktadır. Bireysel faktörler değerlendirilmek istendiğinde; 
cinsiyet, din, aynı iş yerinde çalışılan süre, toplam çalışılan süre, emekliliğe kadar çalışılması gereken süre, duygusal zekâ, zekâ, eğitim öğretim durumu ve ruh sağllğı gibi değişkenlerdir (Sönmezer, 2007). Örgütsel faktörler incelendiğinde ise; çalışanın hak ve yan hakları, iş güvenliği ve güvencesi, yapılan işin niteliği, çalışılan kurumun oluşturmuş olduğu algı, yönetim politikaları, iş yeri koşulları, iş yerinde bulunan sosyal çevre, iş gücü devri, kariyer yolunun varlığı ve şeffaflığı, verimlilik, sendika ile ilişkiler, esnek zaman ve mekân imkanları gibi faktörlerdir (Sönmezer ve Eryaman, 2008; Toker, 2007; Bingöl, 2001; Eren, 2001).

İşten ayrılma niyeti, çalışanın organizasyondan ayrılmaya bilinçli bir şekilde karar vermesi veya niyet etmesi olarak tanımlanmıştır (Sabuncuoğlu, 2007). Anlaşılacağı üzere işten ayrılma niyeti işten ayrılma ile sonuçlanmak zorunda değildir. Yani işten ayrılma niyeti her zaman iş görenin organizasyon ile yollarını ayırmasına neden olmayabilir (Mobley, 1982). İşten ayrılma niyeti oluştuğunda iş gören verdiği karar çerçevesinde uygun zemin oluştuğunda işten ayrılabilecektir, ancak bu işten ayrılma niyetini oluşturan karar ile tamamen farklı bir karar olabilecektir. Ancak belirtmek gerekir ki işten ayrılma niyetinin oluşması, işten ayrılmaya sebep olmamış olsa da iş görenin iş hayatını ve performansını olumsuz yönde ve doğrudan etkilemektedir (Ünlüsoy Dinçer, 2010). Buda bize göstermektedir ki işten ayrılma niyetinin ve bu niyeti oluşturan faktörlerin tespiti örgüt için çok önemlidir. Literatürde yapılan değerlendirmelerde işten ayrılma niyetinin nedenleri çoklukla bireysel ve örgütsel olarak iki grup halinde incelenmiştir. Örgütsel faktörler örgüt içerisinde çalışanların hissettiği adalet, örgüte olan bağlılık, devamlılık, bireyin hissetmiş olduğu tükenme hissi, iş tatmini, çalışana veya çevresine uygulanan mobbing gibi hususlardır. Çalışanların iş ve özel hayatları arasındaki dengede oluşabilecek değişikler de işten ayrılma niyetinin ortaya çıkmasına neden olabilmektedir. İşten ayrılma niyeti ile yapılmakta olan iş için hissedilen duygusal bağllılı arasında ters yönlü bir etkileşim bulunduğu tespit edilmiştir (Kim ve diğ., 2015). Örgütsel bağlılık arttıkça işten ayrılma niyeti azalmakta ve aksi durumda da işten ayrılma niyeti artmaktadır (Uyguç ve Çımrın, 2004; Wasti ve Önder, 2002; Clugston, 2000). Örgütsel bağlllığa ek olarak işten duyulan tatminin de işten ayrılma niyetini etkilediği ortaya çıkmıştır (Martin ve 
Shore, 1989). Çalışan yaptığı işten ve yaptığı işin çıktısının örgüt için olan değerinden tatmin oluyor ise hem örgüt bağlılığı artmakta hem de işten ayrılma niyeti azalmaktadır (Poyraz ve Kama, 2008). Ancak bu gibi değerlendirmeler yapılırken olumsuz ekonomik koşulların ve iş olanaklarında dönemsel olarak yaşanabilen düşüşlerinde göz önünde bulundurulması gerekmektedir. Öyle ki iş bulma umudu olmayan bir çalışanın işten ayrılma niyetinin düşük olması örgütsel bağl1lı̆̆ının yüksek olduğu anlamına gelmemektedir (Agin, 2010).

Bireysel Faktörler ise şu şekilde açıklanmaktadır. Çalışanlar, kendilerini geliştirdiklerini düşündüklerinde, örgüt tarafından düzenli olarak niteliklerini arttırmaya yönelik eğitim ve faaliyetlere tabi tutulduklarında hem örgüt bağlllığı artmakta hem de işten ayrılma niyeti azalmaktadır (Agin, 2010). Ayrıca bireylerin kişilik özellikleri ile işten ayrılma niyetleri arasında da etkileşim bulunmaktadır. Çalışanların kişisel yeterlilik duygusu, kendine saygı, öz kontrol ve bireysel saygı gibi olumlu kişisel özelliklerin yüksek olması halinde işten ayrılma niyetinin daha düşük ve tam aksi durumda ise işten ayrılma niyetinin daha yüksek olduğu gözlemlenmiştir (Akgündüz ve diğ., 2014).

Psikolojik sermaye kavramı Luthans, Youssef ve Avolio tarafindan ortaya konmuştur. Yaptıkları değerlendirmelerde psikolojik sermaye kavramı bireyin içinde bulunduğu olumlu psikolojik durumu oluşturan dört ana bileşenden oluştuğunu öne sürmüşlerdir. Psikolojik Sermaye, 'bireyin üstünden gelmesi zor olan görevlerde başarı göstereceğine dair kendisine güvenmesi (öz - yeterlilik), görevin başarılacağına ilişkin olarak şuan ve gelecek bir zamanda pozitif bir yaklaşımın olması (iyimserlik), görevi başarı ile sonuçlandırmak adına sonuca ulaşana kadar direnmesi ve bu süreç içerisinde pes etmeden farklı yollar denemesi (umut) ve sonuca ulaşmak adına karşılaşılan sorun ve zorluklar ile mücadelede yılmazlık (dayanıklılık) göstermesi olmak üzere 4 ana bileşenden oluşmaktadır (Youssef ve Luthans, 2009). Psikolojik sermaye kavramı bireylerin pozitif enerjilerinin açıklanması için de kullanılmıştır (Zhao ve Hou, 2009). Günümüz dünyasında tüm teknolojik ve sosyolojik değişimler her alanı etkilediği gibi iş hayatını da doğrudan ve derinden etkilemektedir. Bu bağlamda çalışanların bireysel beklentileri de daha önceki yıllara göre köklü şekilde değişmektedir. Yapılmakta olan iş ve görülen göreve göre bireyde oluşan iş tatminine ilişkin doyuma ulaşılan 
seviye ile mutlu olunan seviyedeki düşüş ve yükselişler benzerlik göstermektedir. Netice olarak birey mutlu olmak adına işinde tatmin olmayı beklemektedir. Ancak mevcut güncel zorunluluklar ve kurumsal araçlar ile seçilen psikolojik yaklaşımlar bu durumun karşılaması için yeteri kadar etkili olamamaktadır (Seligman ve Csikszentmihalyi, 2000). Psikolojik sermaye yaklaşımında bireylerin içinde bulundukları pozisyon değil gelecek dönemlerde olacakları pozisyon değerlendirilmektedir (Walumbwa ve diğ., 2011). Önemli olan kişinin ulaşabileceği potansiyeldir. Bu potansiyelin dışarı çıkarılması için değişkenlerin tespiti ve değerlendirilmesi gerekmektedir (Jarden, 2012).

Daha önce belirtildiği gibi psikolojik sermaye kavramının "öz yeterlilik", "umut", "iyimserlik" ve "dayanıklılık" olmak üzere dört alt boyutu vardır.

Öz Yeterlilik, kişinin her hangi bir görevi başarı ile tamamlaması için gerekli yetkinliklere sahip olduğuna olan güveni ve inancıdır (Bandura, 1993, 1982, 1977). Öz yeterlilik kavramının çalışma ortamında değerlendirildiğinde tanım görevin istenilen şekilde başarılı olarak tamamlanabilmesi için çalışanın gerekli olan davranışları kurgulama ve uygulama konusunda başarılı olabileceğine dair inanç olarak ifade edilmektedir (Stajkovic ve Luthans, 1998). Öz yeterlilik durağan bir kavram değildir ve hem bireyin hem örgütün içinde bulunduğu yapı ve anlık durumlar bu olguyu doğrudan etkilemektedir. Bu açıdan değerlendirildiğinde belirgin bir esnekliğinin olduğundan söz etmek mümkündür (Pajares, 2009).

Umut alt boyutu ile ilgili olarak, insanlar olası gelecekleri için birbirinden farklı durumları değerlendirerek kendi lehlerine veya aleyhlerine gelişebilecek ihtimaller için umut, korku, endişe ve heyecan gibi hislerin oluşmasına neden olmaktadır. Geleneksel tanımı ile umut durumun kötüleştiği anlarda her şeyin düzeleceğine ve kötüye giden durumun düzeleceğine olan inanç ve beklentidir (Luthans ve diğ., 2004).. Umut düzeyi yüksek olan çalışanlardan oluşan ekiplerdeki çalışan işten ayrılma oranı umut düzeyi daha düşük olan çalışanlardan oluşan ekiplerden işten ayrılma oranına göre daha düşüktür. Bundan dolayı liderlerin ve çalışanlar umut düzeyinin iyileştirilmesi insan kaynağ yönetimi açısından çok önemlidir (Luthans ve Jensen, 2002). 
İyimserlik bireyin durumların ve olayların gerekçelerine ilişkin pozitif tutumun negatif tutuma nazaran daha yoğun olarak ortaya çıması şeklinde açılanmaktadır (Seligman ve diğ., 2006). İyimserlik ve umut beraber incelendiğinde kişinin öz saygısını ve moralini olumlu yönde anlamlı bir şekilde etkilediği görülmektedir (Luthans ve Youssef, 2004). İyimser olma özelliği daha yüksek olarak ölçülmüş olan kimseler kazanılmış bir başarı karşısında bu durumu sıklıkla karşılaşılan bir durum olarak görürler ve olumlu bir motivasyon kaynağg olarak bu durumdan beslenirler (Luthans ve diğ., 2004).

Dayanıklılık ise belirgin risklere karşın kendini iyi bir şekilde ayakta tutma ve performansını olması gerektiği gibi devam ettirme yeteneğidir. Çalışırken karşılaşılan belirsizlikler, çalışma ortamında artan stres, kimi durumlarda başarısız olma karşısında hızlıca toparlanma ve yeniden durumun şart ve gerekliliklerine göre performansı olması gerektiği düzeyde tutma gibi davranışlar kişinin dayanıklı olduğunu gösterir (Luthans, 2002).

\section{Araştırmanın Yöntemi ve Veri Toplama Araçları}

Çalışma nicel bir saha araştırması desenine sahiptir. Veri toplama aracı olarak anket tercih edilmiştir. Geçerli ve güvenilir ölçeklerden oluşan anket, yüksek lisans tez çalışması esnasında 2019 yılında uygulanmış ve veriler elde edilmiştir. 45 adet anketin basılı form olarak, ilgililer tek tek bilgilendirilerek doldurulması sağlanmıştır. 237 adet anket ise Google/Docs ve SurveyMonkey uygulaması ile online olarak doldurulmuştur. İlk olarak Google/Docs uygulaması aracılığı ile anket oluşturulmuş ve veriler toplanmıştır. Ancak bazı kurumsal firmaların güvenlik kısıtlamaları nedeni ile Google/Docs aracılığıyla anket erişimi sağlanamadığından, verilerin toplanabilmesi için erişim engeli bulunmayan SurveyMonkey uygulaması kullanılmıştır. Elde edilen veriler, tanımlayıc1 ve tahmin edici istatistik analizlerine tabii tutulmuştur.

Araştırma evreni İstanbul Levent bölgesinde, finans sektöründe faaliyet gösteren, iki kurumda çalışan 347 beyaz yakalıdan oluşmaktadır. Öncelikle amaçlı örneklem yöntemi ile söz konusu bu iki kurumda çalışan finans alanında uzman 203 kişi seçilmiştir. Ayrıca sektör açısından 
araştırma değişkenlerinin farklılaşmasını incelemek üzere finans sektörü dışında 79 çalışan rastgele ve kolayda örneklem yöntemiyle örnekleme dahil edilmiştir. Bu sayede örneklemde 282 katılımcı olmuştur (Dattalo, 2008; Schoot ve Miocević, 2020; Verma ve Verma, 2020). Ankete katılanların tamamı bir yöneticiye bağlı olarak çalışmaktadırlar.

Araştırmada örneklem grubundan veri toplamak için hazırlanan anket 3 bölümden oluşmaktadır. Anketin birinci bölümünde lider üye etkileşimine, işten ayrılma niyetine ve iş tatminine ilişkin sorular vardır. Lider-üye etkileşimini ölçmek için Liden ve Maslyn (1998) tarafından geliştirilen, Baş, Keskin ve Mert'in (2010) Türkçe'ye adapte ettikleri, geçerlik ve güvenirlilik analizini gerçekleştirdikleri ölçek kullanılmıştır. İşten ayrılma niyeti değişkeni ise Mobley, Horner ve Hollingsworth (1978) tarafından geliştirilen, Örücü ve Özafşarlıŏlu'nun (2013) Türkçe'ye adapte ettikleri, geçerlik ve güvenirlilik analizini gerçekleştirdikleri ölçek kullanılmıştır. İş tatmini değişkeni içinse, Wright ve Cropanzano (1998) tarafından geliştirilen, Rızaoğlu ve Ayyıldız'ın (2008) Türkçe'ye adapte ettikleri, geçerlik ve güvenirlilik analizini gerçekleştirdikleri ölçek kullanılmıştır. Birinci bölümde katılımcılardan, 5 ölçekli bir skalada katılma derecelerini belirtmeleri istenen 20 adet ifade bulunmaktadır.

Anketin ikinci bölümünde araştırmanın diğer değişkenlerinden psikolojik sermayeyi ölçmek için Luthans, Avolio, Avey ve Norman (2007) tarafından geliştirilen, Erkuş ve Fındıklı'nın (2013) Türkçe'ye adapte ettikleri, geçerlik ve güvenirlilik analizini gerçekleştirdikleri ölçek kullanılmıştır. Hazırlanmış olan 24 adet ifadeye katılımcıların 5 ölçekli bir skalada katılma derecelerini belirtmeleri istenmiştir.

Anketin son bölümü olan üçüncü bölümde ise katılımcıların demografik durumlarını tespit etmek için 7 adet soru bulunmaktadır. Katılımcıların cinsiyet, yaş aralığı, eğitim düzeyi, iş deneyimi, finans sektörü veya başka bir sektörde çalışıp çalışmadığı bu kısımda belirlenmiştir.

Araştırma Modeli ve Hipotezler: Araştırma modelinde ikişer aded bağımsız ve bağımlı değişken vardır. "Lider-üye etkileşimi" ve "psikolojik sermaye" bağımsız değişken iken, "iş tatmini" ve "işten ayrılma niyeti" bağımlı değişkendir. 


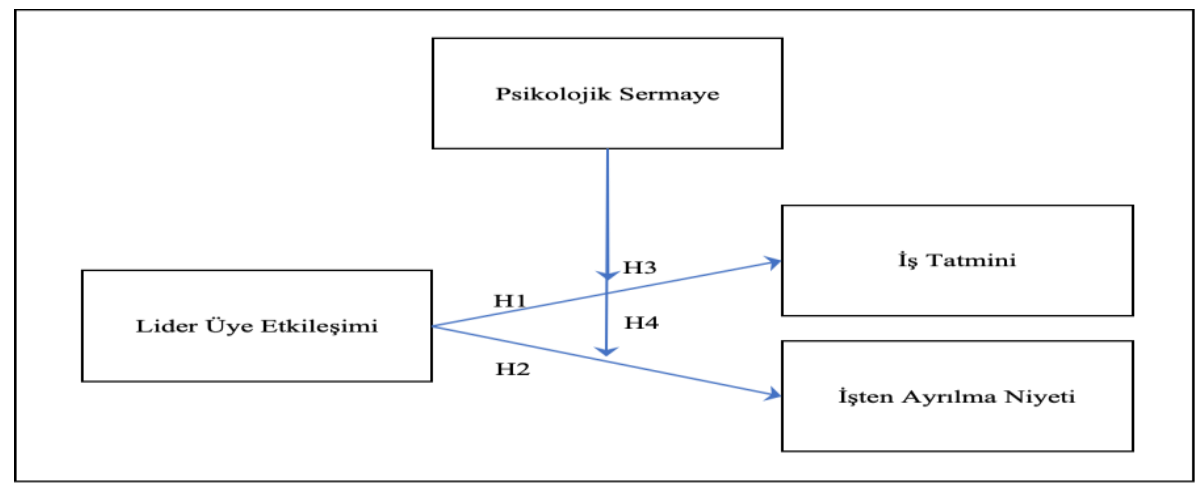

Şekil 1. Araştırma Modeli

Araştırma modelinde belirtilen ilişkiler neticesinde ortaya çıkan hipotezler;

H1: Lider-üye etkileşimi, iş tatminini etkiler.

$\mathrm{H} 2$ : Lider-üye etkileşimi, işten ayrılma niyetini etkiler.

H3: Lider-üye etkileşiminin, iş tatminini etkisinde psikolojik sermayenin düzenleyici rolü vardır.

H4: Lider üye etkileşiminin, işten ayrılma niyetine etkisinde psikolojik sermayenin düzenleyici rolü vardır.

\section{Bulgular}

Çalışmada örneklem grubundan elde edilmiş olan veriler IBM SPSS 25 paket programı vasıtası ile analize tabi tutulmuştur. Tanımlayıcı istatistik kapsamında katılımcılara ilişkin frekanslar ve yüzdeler hesaplanmıştır. Tahmin edici istatistik analizler kapsamında normallik, faktör, güvenilirlik, farklılık, korelasyon, regresyon ve düzenleyici etki analizleri yapılmıştır.

\section{Tanımlayıcı İstatistik Bulguları}

Katılımclara ait demografik bulgular Tablo 1'de sunulmuştur. 
Lider Üye Etkileşiminin İş Tatmini ve İşten Ayrılma Niyetine Etkisinde Psikolojik Sermayenin Düzenleyici Rolü

Tablo 1. Demografik Bulgular

\begin{tabular}{|c|c|c|c|}
\hline Demografik Bilgiler & & Frekans (n) & $\%$ \\
\hline Cincivet & "Kadın" & 169 & $60 \%$ \\
\hline Cinsiyet & “Erkek" & 113 & $40 \%$ \\
\hline & "25 yaş altı" & 8 & $3 \%$ \\
\hline & "26 - 35 yaş arası" & 170 & $60 \%$ \\
\hline Yaş & "36 - 45 yaş arası" & 94 & $33 \%$ \\
\hline & "46 - 55 yaş arası" & 9 & $3 \%$ \\
\hline & “56 ve üzeri” & 1 & $0 \%$ \\
\hline & "Lise" & 13 & $5 \%$ \\
\hline Fŏitim Dïzovi & “Ön Lisans" & 11 & $4 \%$ \\
\hline Egitim Duzeyi & "Lisans" & 160 & $57 \%$ \\
\hline & "Lisansüstü" & 98 & $35 \%$ \\
\hline Katulımcların Calıstı̆̆̆ Sektör & "Finans Sektörü" & 203 & $72 \%$ \\
\hline 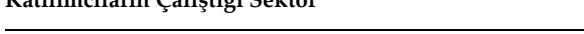 & "Diğer Sektör" & 79 & $28 \%$ \\
\hline & "0 - 2 yıl" & 74 & $26 \%$ \\
\hline Katulumclarun Mevcut İslerinde Calısma Süresi & "3 - $6 \mathrm{yll}^{\prime \prime}$ & 124 & $44 \%$ \\
\hline Katılımciların Mevcut Işıerınde Çalışma Suresı & "7 - $10 \mathrm{y1l} "$ & 37 & $13 \%$ \\
\hline & “11 ve üzeri" & 47 & $17 \%$ \\
\hline & "0 - 2 yil" & 27 & $10 \%$ \\
\hline Katulumclarnn Meycut Settörde Tonlam Calıma Sïresi & “3 - 6 yll” & 85 & $30 \%$ \\
\hline Katılımciların Mevcut Sektorde Ioplam Çalışma Suresı & “7 - $10 \mathrm{yll}^{\prime \prime}$ & 66 & $23 \%$ \\
\hline & 11 ve üzeri & 104 & $37 \%$ \\
\hline & "0 - 2 yıl" & 12 & $4 \%$ \\
\hline & "3 - 6 yll" & 56 & $20 \%$ \\
\hline Katılımciların Iopıam Çalış̧ma Suresı & "7 - $10 \mathrm{yll}^{\prime}$ & 69 & $24 \%$ \\
\hline & “11 ve üzeri” & 145 & $51 \%$ \\
\hline
\end{tabular}

Tablo 1 incelendiğinde kadınların (\%60) erkek (\%40) katılımcılardan fazla olduğu görülmüştür. Yaş bakımından aktif çalışma yaşıyla ilintili olarak büyük çoğunluğunun 26-45 (\%93) yaş aralığında olduğu tespit edilmiştir. Eğitim düzeyi bakımından lisans mezunları (\%57) çoğunluğu oluşturmaktadır. Katılımcıların kurum ve sektör çalışma sürelerinin dengeli dağıldığı görülmüştür.

\section{Normallik Analizi}

SPSS paket programı aracılığ 1 ile lider üye etkileşimi, işten ayrılma niyeti, iş tatmini ve psikolojik sermaye için ayrı ayrı normallik analizi gerçekleştirilmiştir.

Tablo 2. Çarpıklık ve Basıklık

\begin{tabular}{lll}
\hline Değişkenler & Çarpıklık (Skewness) & Basıklık (Kurtosis) \\
\hline Lider Üye Etkileşimi & $-0,708$ & 0,070 \\
İşten Ayrılma Niyeti & 0,335 & $-0,757$ \\
İş Tatmini & $-0,406$ & 0,142 \\
Psikolojik Sermaye & $-0,518$ & 1,276 \\
\hline
\end{tabular}


Elde edilen verilerin normallik düzeyine uygun olup olmadığına karar verebilmek için normallik (Kolmogorov-Smirnov) analizi uygulanmıştır. Sonuçlara göre verilerin dağılımının normal olmadığı görülmüştür $(p<0,05)$. Dolayısıyla çarpıklık ve basıklık değerleri dikkate alınmıştır. Normallik analizinde çarpıklık ve basıklık değerleri kabul edilebilir (-1,96 ile $+1,96)$ aralıklarda olması durumunda, sosyal bilimlerde normal dağılımdan söz edilebilir (Tabachnick and Fidell, 2007). Bu yaklaşıma göre tablo 2 incelendiğinde değişkenlerin kabul edilebilir aralıklarda olduğu ve normal dağılıma sahip olduğu varsayılmıştır.

\section{Faktör Analizleri}

Yapılmış olan anket çalışması kapsamında alt boyutlara sahip lider üye etkileşimi ve psikolojik sermaye çıtılarının faktör analizine konu olup olmayacağına Kaiser-Meyer-Olkin (KMO) ve Barlett testleri uygulanarak karar verilebilmiştir.

Tablo 3. Faktör Analizi

\begin{tabular}{lll}
\hline & Lider Üye Etkileşimi & Psikolojik Sermaye \\
\hline TOPLAM VARYANS & 84,961 & 58,983 \\
KMO DEĞERİ & 0,936 & 0,913 \\
BARTLETT KÜRESELLIK TESTI (Kİ-KARE) & 3108,072 & 2653,593 \\
SERBESTLIK DERECESİ & 66 & 210 \\
P (ANLAMLILIK) DEĞERİ & 0,000 & 0,000 \\
FAKTÖR SAYISI & 4 & 4 \\
\hline
\end{tabular}

Lider-üye etkileşimi ve psikolojik sermaye değişkenlerinin orijinal ölçkelerdeki gibi faktörleştiği görülmüştür (Tablo 3). Ancak psikolojik sermaye ölçeği faktör analizi sonrasında yirmi bir ifadeye indirgenmiştir. Umut faktöründe yer alan "Bir problemin pek çok çözüm yolu vardır" ifadesi iyimserlik faktörüne aktarılmıştır. Dayanıklılık faktöründe yer alan "İşte başarısız olduğumda, bundan kurtulmakta ve yoluma devam etmekte zorlanıyorum", iyimserlik faktöründe yer alan "İşimle ilgili bazı şeylerin ters gitme ihtimali varsa gidecektir", "İşimle ilgili hiçbir şey istediğim şekilde gitmez" ifadelerinin faktör yükleri yetersiz bulunduğundan ölçekten çıkarılmıştır. 


\section{Güvenilirlik Analizi}

Güvenilirlik, kendi içindeki tutarlılığ gösterir. Cronbach Alpha değeri 0,50 ve üzeri değişkenler iç tutarlılık güvenilirliği sağlanmış kabul edilmektedir (Nunnally, 1994).

Tablo 4. Güvenilirlik Değerleri

\begin{tabular}{|c|c|c|c|c|}
\hline Değişkenler & Alt Boyutlar & Soru Sayısı & $\begin{array}{l}\text { Cronbach Alpha }(*) \\
\text { Değerleri Alt Boyutlar }\end{array}$ & $\begin{array}{l}\text { Cronbach Alpha } \\
\text { (*) Değerleri }\end{array}$ \\
\hline \multirow{4}{*}{ Lider Üye Etkileşimi } & "Etki" & 3 & 0,925 & \multirow{4}{*}{0,954} \\
\hline & "Vefakârlık" & 3 & 0,902 & \\
\hline & "Katkı" & 3 & 0,851 & \\
\hline & "Profesyonel Saygi" & 3 & 0,934 & \\
\hline İşten Ayrılma Niyeti & & 3 & & 0,891 \\
\hline İş Tatmini & & 5 & & 0,752 \\
\hline \multirow{4}{*}{ Psikolojik Sermaye } & "Öz Yeterlilik" & 6 & 0,891 & \multirow{4}{*}{0,902} \\
\hline & “Umut" & 5 & 0,818 & \\
\hline & "Dayanıklılık" & 5 & 0,739 & \\
\hline & "İyimserlik" & 5 & 0,696 & \\
\hline
\end{tabular}

Tablo 4'te değerler incelendiğinde kullanılan ölçeklerin oldukça ve yüksek derece güvenilirliğe sahip olduğu görülmektedir.

\section{Farklılık Analizi}

Araştırmanın demografik bilgilerinde yer alan cinsiyet, yaş, eğitim, sektör, deneyim verilerine ilişkin farklılık analizi çalışmaları ve sonuçlarına bu bölümde yer verilmiştir. İlk demografik bilgi olan cinsiyet verisinde farklılık analizi için SPSS programında Independent-Samples T testi uygulanmıştır.

Tablo 5. Cinsiyet bakımından farklılık analizi

\begin{tabular}{|c|c|c|c|c|c|c|c|}
\hline & Grup & $\mathbf{n}$ & Ort. & ss & $\mathbf{t}$ & sd & $p$ \\
\hline \multirow{2}{*}{ LMX } & K & 169 & 3,3949 & 0,9342 & \multirow{2}{*}{$-0,541$} & \multirow{2}{*}{280} & \multirow{2}{*}{0,589} \\
\hline & E & 113 & 3,4572 & 0,9655 & & & \\
\hline \multirow{2}{*}{ IAN } & K & 169 & 2,5819 & 1,0917 & \multirow{2}{*}{$-1,022$} & \multirow{2}{*}{280} & \multirow{2}{*}{0,308} \\
\hline & E & 113 & 2,7198 & 1,1379 & & & \\
\hline \multirow{2}{*}{ IST } & K & 169 & 3,3479 & 0,7179 & \multirow{2}{*}{$-1,416$} & \multirow{2}{*}{280} & \multirow{2}{*}{0,158} \\
\hline & $\mathrm{E}$ & 113 & 3,4726 & 0,7334 & & & \\
\hline \multirow{2}{*}{ PS } & $\mathrm{K}$ & 169 & 3,9003 & 0,4324 & \multirow{2}{*}{$-1,607$} & \multirow{2}{*}{280} & \multirow{2}{*}{0,109} \\
\hline & E & 113 & 3,9874 & 0,4664 & & & \\
\hline
\end{tabular}


Tablo 5'te cinsiyet verilerine göre yapılan farklılık analizinin sonuçları yer almaktadır. Lider üye etkileşimine ait anlamlılık değeri 0,589, işten ayrılma niyetine ait anlamlılık değeri 0,308 , iş tatminine ait anlamlılık değeri 0,158 , psikolojik sermayeye ait anlamlılık değeri 0,109'dur. Yani tüm değişkenlerin değerlerini incelediğimizde değişkenlerin cinsiyet bakımından farklılaşmadığı sonucuna varılmıştır.

Tablo 6. Yaş bakımından farklılık analizi

\begin{tabular}{llll}
\hline & $\begin{array}{l}\text { Mean Square (Gruplar } \\
\text { Arasi) }\end{array}$ & $\mathbf{f}$ & Sig. (p) \\
\hline LMX & 3,242 & 3,768 & 0,005 \\
IAN & 1,312 & 1,065 & 0,374 \\
IST & 0,767 & 1,467 & 0,213 \\
PS & 0,113 & 0,558 & 0,693 \\
\hline
\end{tabular}

İkinci demografik bilgi olan yaş verisinde farklılık analizi için SPSS programında One Way Anova analizi uygulanmıştır. Tablo 6'da yaş verilerine göre yapılan farklılık analizinin sonuçları yer almaktadır. İşten ayrılma niyeti, iş tatmini ve psikolojik sermaye değişkenlerine ait anlamlılık değerleri büyük olduğu için dağılımların homojen olduğu, yaş bakımından farklılaşmadığı sonucuna varılmıştır. Ancak lider üye etkileşimi anlamlılık değeri 0,005 olduğu için yaş bakımından anlamlı bir şekilde farklılaşmaktadır. Bu sebeple yaş bakımından farklılık analizinde lider üye etkileşimi için post-hoc tukey testi gerçekleştirilmiştir.

Tablo 7. Lider üye etkileşiminde yaş bakımından farklılık analizi

\begin{tabular}{|c|c|c|c|c|c|c|}
\hline (I) YAŞ & (J) YAŞ & $\mathbf{N}$ & Ort. & $\begin{array}{l}\text { Ort. Farklılığ } \\
\text { (I-J) }\end{array}$ & Std. Hata & Sig. (p) \\
\hline \multirow{3}{*}{$\begin{array}{l}25 \text { yaş } \\
\text { altı }\end{array}$} & $26-35$ yaş arası & \multirow{3}{*}{8} & \multirow{3}{*}{3,9474} & 0,39521 & 0,33557 & 0,6410 \\
\hline & $36-45$ yaş arası & & & 0,74237 & 0,34161 & 0,1330 \\
\hline & $46-55$ yaş arası & & & 0,74304 & 0,45071 & 0,3530 \\
\hline \multirow{3}{*}{$\begin{array}{l}26-35 \\
\text { yaş arası }\end{array}$} & 25 yaş altı & \multirow{3}{*}{170} & \multirow{3}{*}{3,5422} & $-0,39521$ & 0,33557 & 0,6410 \\
\hline & $36-45$ yaş arası & & & $0,34716^{*}$ & 0,11922 & 0,0200 \\
\hline & $46-55$ yaş arası & & & 0,34783 & 0,31726 & 0,6920 \\
\hline \multirow{3}{*}{$\begin{array}{l}36-45 \\
\text { yaş arası }\end{array}$} & 25 yaş altı & \multirow{3}{*}{94} & \multirow{3}{*}{3,195} & $-0,74237$ & 0,34161 & 0,1330 \\
\hline & $26-35$ yaş arası & & & $-0,34716^{*}$ & 0,11922 & 0,0200 \\
\hline & $46-55$ yaş arası & & & 0,00067 & 0,32365 & 1,0000 \\
\hline \multirow{3}{*}{$\begin{array}{l}46-55 \\
\text { yaş arası }\end{array}$} & 25 yaş altı & \multirow{3}{*}{9} & \multirow{3}{*}{3,1943} & $-0,74304$ & 0,45071 & 0,3530 \\
\hline & $26-35$ yaş arası & & & $-0,34783$ & 0,31726 & 0,6920 \\
\hline & $36-45$ yaş arası & & & $-0,00067$ & 0,32365 & 1,0000 \\
\hline Total & & 281 & 3,4261 & & & \\
\hline
\end{tabular}

${ }^{*} p<0,05$ 
Lider üye etkileşiminde yaş değişkeninde hangi alt gruplar arasında farklılaşma olduğu tablo 7'de gösterilmiştir. Yapılan tukey testinde "2635" yaş ile “36-45" yaş gruplarında anlamlı farklılaşma olduğu görülmüştür $(\mathrm{p}<0,05)$. Bu durum "26-35" yaş aralığındaki çalışanların, "36-45" yaş aralığındaki çalışanlara göre lider üye etkileşim düzeylerinin daha yüksek olduğunu ortaya koymaktadır. Diğer alt gruplarda yer alan yaş gruplarında değişkenlerin istatiksel olarak farklılışmadığı tespit edilmiştir $(p<0,05)$. Alt gruplardan "56 ve üzeri" yaş grubunda bir adet veri olduğundan tukey testine dahil edilememiştir.

Tablo 8. Ĕ̈itim bakımından farklılık analizi

\begin{tabular}{llll}
\hline & $\begin{array}{l}\text { Mean Square (Gruplar } \\
\text { Arası) }\end{array}$ & $\mathbf{f}$ & Sig. (p) \\
\hline LMX & 1,334 & 1,500 & 0,215 \\
IAN & 2,592 & 2,128 & 0,097 \\
IST & 1,059 & 2,035 & 0,109 \\
PS & 0,284 & 1,426 & 0,235 \\
\hline
\end{tabular}

Üçüncü demografik bilgi olan eğitim verisinde farklılık analizi için SPSS programında One Way Anova analizi uygulanmıştır. Tablo 8'de eğitim verilerine göre yapılan farklılık analizinin sonuçları görülmektedir. Lider-üye etkileşimi, işten ayrılma niyeti, iş tatmini ve psikolojik sermaye değişkenlerine ait anlamlılık değerleri $(p>0,05)$ incelendiğinde değişkenlerin eğitim bakımından farklılaşmadığı sonucuna varılmıştır.

Tablo 9. Çalışılan sektör bakımından farklılık analizi

\begin{tabular}{|c|c|c|c|c|c|c|c|}
\hline & Grup & $\mathbf{n}$ & Ort. & ss & $t$ & sd & $p$ \\
\hline \multirow{2}{*}{ LMX } & Finans Sektörü & 203 & 3,4984 & 0,9301 & \multirow{2}{*}{2,249} & \multirow{2}{*}{280} & \multirow{2}{*}{0,025} \\
\hline & Diğer Sektör & 79 & 3,2183 & 0,9614 & & & \\
\hline \multirow{2}{*}{ IAN } & Finans Sektörü & 203 & 2,5583 & 1,0682 & \multirow{2}{*}{$-1,920$} & \multirow{2}{*}{280} & \multirow{2}{*}{0,056} \\
\hline & Diğer Sektör & 79 & 2,8397 & 1,1958 & & & \\
\hline \multirow{2}{*}{ IST } & Finans Sektörü & 203 & 3,4138 & 0,7029 & \multirow{2}{*}{0,590} & \multirow{2}{*}{280} & \multirow{2}{*}{0,556} \\
\hline & Diğer Sektör & 79 & 3,3570 & 0,7836 & & & \\
\hline \multirow{2}{*}{ PS } & Finans Sektörü & 203 & 3,9505 & 0,4075 & \multirow{2}{*}{0,819} & \multirow{2}{*}{114} & \multirow{2}{*}{0,415} \\
\hline & Diğer Sektör & 79 & 3,8957 & 0,5380 & & & \\
\hline
\end{tabular}

Dördüncü demografik bilgi olan çalışılan sektör verisinde farklılık analizi için SPSS programında Bağımsız-Örneklemler $\mathrm{T}$ Testi uygulanmıştır. Tablo 9'da çalışılan sektör verilerine göre yapılan farklılık analizinin sonuçları yer almaktadır. Lider-üye etkileşimine ait anlamlılık 
değeri 0,025, işten ayrılma niyetine ait anlamlılık değeri 0,056, iş tatminine ait anlamlılık değeri 0,556, psikolojik sermayeye ait anlamlılık değeri 0,415 'dir. İşten ayrılma niyeti, iş tatmini ve psikolojik sermaye değişkenlerinin çalışılan sektör bakımından farklılaşmadığı sonucuna varılmıştır. Lider üye etkileşimi anlamlılık değeri $(p<0,05)$ küçük olduğu için çalışılan sektör bakımından farklılaştığı tespit edilmiştir. Finans sektörü çalışanlarının lider üye etkileşim düzeyleri $\left(\mathrm{x}^{-}=3,4984\right)$, diğer sektör çalışanlarının lider üye etkileşim düzeylerinden yüksektir $\left(\mathrm{x}^{-}=3,2183\right)$.

Tablo 10. Mevcut çalışılan firmadaki çalışma süresi bakımından farklılık analizi

\begin{tabular}{llll}
\hline & Mean Square (Gruplar & f & Sig. (p) \\
\hline Arasi) & 2,573 & 2,936 & 0,034 \\
IAN & 0,845 & 0,683 & 0,563 \\
IST & 1,478 & 2,865 & 0,037 \\
PS & 0,342 & 1,723 & 0,162 \\
\hline
\end{tabular}

Beşinci demografik bilgi olan mevcut çalışılan firmadaki çalışma süresi verisinde farklılık analizi için SPSS programında One Way Anova analizi uygulanmıştır. Tablo 10 'da mevcut çalışılan firmadaki çalışma süresi verilerine göre yapılan farklılık analizinin sonuçları yer almaktadır. İşten ayrılma niyeti ve psikolojik sermaye değişkenlerine ait anlamlılık değerleri $(p>0,05)$ büyük olduğu için dağllımların homojen olduğu, mevcut çalışılan firmadaki çalışma süresi bakımından farklılaşmadığ sonucuna varılmıştır. Ancak lider üye etkileşimi ve iş tatmini değişkenlerine ait anlamlılık değeri $(p<0,05)$ küçük olduğu için mevcut çalışılan firmadaki çalışma süresi bakımından her iki değişken de anlamlı bir şekilde farklılaşmaktadır. Bu sebeple mevcut çalışılan firmadaki çalışma süresi bakımından farklılık analizinde lider üye etkileşimi ve iş tatmini değişkenleri için post-hoc tukey testi gerçekleştirilmiştir. 
Tablo 11. Lider üye etkileşiminde mevcut çalışılan firmadaki çalışma süresi bakımından farklılık analizi

\begin{tabular}{|c|c|c|c|c|c|c|}
\hline $\begin{array}{l}\text { (I) Mevcut Çalışılan } \\
\text { Firmadaki Çalışma Süresi }\end{array}$ & $\begin{array}{l}\text { (J) Mevcut Çalışılan } \\
\text { Firmadaki Çalışma Süresi }\end{array}$ & $\mathbf{N}$ & Ort. & $\begin{array}{l}\text { Ort. } \\
\text { farklılığ1 (I- } \\
\text { J) }\end{array}$ & $\begin{array}{l}\text { Std. } \\
\text { Hata }\end{array}$ & $\begin{array}{l}\text { Sig. } \\
\text { (p) }\end{array}$ \\
\hline \multirow{3}{*}{$0-2 Y_{1} 1$} & 3-6 Y 11 & & & $0,36196^{*}$ & 0,13750 & 0,044 \\
\hline & 7-10 Y 11 & 74 & 3,6960 & 0,41223 & 0,18847 & 0,129 \\
\hline & 11 ve üzeri & & & 0,37685 & 0,17459 & 0,138 \\
\hline \multirow{3}{*}{ 3-6 Yil } & $0-2 Y_{1} l$ & & & $-0,36196^{*}$ & 0,13750 & 0,044 \\
\hline & 7-10 $\mathrm{Y}_{11}$ & 124 & 3,3340 & 0,05027 & 0,17534 & 0,992 \\
\hline & 11 ve üzeri & & & 0,01489 & 0,16033 & 1,000 \\
\hline \multirow{3}{*}{ 7-10 Yll } & $0-2 Y_{11}$ & & & $-0,41223$ & 0,18847 & 0,129 \\
\hline & 3-6 Y 11 & 37 & 3,2837 & 0,05027 & 0,17534 & 0,992 \\
\hline & 11 ve üzeri & & & 0,01489 & 0,20572 & 0,998 \\
\hline \multirow{3}{*}{11 ve üzeri } & $0-2 Y_{11}$ & & & $-0,37685$ & 0,17459 & 0,138 \\
\hline & 3-6 Yil & 47 & 3,3191 & $-0,01489$ & 0,16033 & 1,000 \\
\hline & 7-10 Y 11 & & & 0,03538 & 0,20572 & 0,998 \\
\hline Total & & 282 & 3,4199 & & & \\
\hline
\end{tabular}

${ }^{*} p<0,05$

Lider üye etkileşiminde mevcut çalışılan firmadaki çalışma süresi değişkeninde hangi alt gruplar arasında farklılaşma olduğu Tablo 11'de gösterilmiştir. Yapılan tukey testinde 0-2 yıl ile 3-6 yıl arası gruplarında bir farklılaşma olduğu görülmüştür $(p<0,05)$. Bu durum 0-2 yıl çalışma süresine ait çalışanların, 3-6 yıl çalışma süresine ait çalışanlara göre lider üye etkileşim düzeylerinin daha yüksek olduğunu ortaya koymaktadır. Diğer alt gruplarda yer alan çalışma süresine ait grupların farklılaşmadığı tespit edilmiştir $(\mathrm{p}>0,05)$.

İş tatmininde mevcut çalışılan firmadaki çalışma süresi değişkeninde hangi alt gruplar arasında farklılaşma olduğu Tablo 12'de gösterilmiştir. Yapılan Tukey testinde alt gruplarda mevcut çalışılan firmadaki çalışma süresine ait grupların farklılışmadığ1 tespit edilmiştir $(p>0,05)$. 
Tablo 12. İş tatmininde mevcut çalışılan firmadaki çalışma süresi bakımından farklilık analizi

\begin{tabular}{|c|c|c|c|c|c|c|}
\hline $\begin{array}{l}\text { (I) Mevcut Çalışılan } \\
\text { Firmadaki Çalışma Süresi }\end{array}$ & $\begin{array}{l}\text { (J) Mevcut Çalışılan } \\
\text { Firmadaki Çalışma Süresi }\end{array}$ & $\mathbf{N}$ & Mean & $\begin{array}{l}\text { Ort. } \\
\text { Farklılığı (I- } \\
\text { J) }\end{array}$ & $\begin{array}{l}\text { Std. } \\
\text { Hata }\end{array}$ & $\begin{array}{l}\text { Sig. } \\
\text { (p) }\end{array}$ \\
\hline \multirow{4}{*}{$0-2 Y_{11}$} & 3-6 Yil & & & 0,24516 & 0,10552 & 0,095 \\
\hline & 7-10 Y 11 & 74 & 3,6000 & 0,35135 & 0,14463 & 0,074 \\
\hline & 11 ve üzeri & & & 0,28936 & 0,13398 & 0,137 \\
\hline & $0-2 Y_{11}$ & & & $-0,24516$ & 0,10552 & 0,095 \\
\hline \multirow[t]{3}{*}{ 3-6 Y 11} & 7-10 Y 11 & 124 & 3,3548 & 0,10619 & 0,13456 & 0,859 \\
\hline & 11 ve üzeri & & & 0,0442 & 0,12304 & 0,984 \\
\hline & $0-2 Y_{11}$ & & & $-0,35135$ & 0,14463 & 0,074 \\
\hline \multirow[t]{3}{*}{ 7-10 Yll } & 3-6 Y 11 & 37 & 3,2486 & $-0,10619$ & 0,13456 & 0,859 \\
\hline & 11 ve üzeri & & & $-0,06199$ & 0,15787 & 0,979 \\
\hline & $0-2 Y_{1}$ & & & $-0,28936$ & 0,13398 & 0,137 \\
\hline \multirow[t]{2}{*}{11 ve üzeri } & 3-6 Y 11 & 47 & 3,3106 & $-0,0442$ & 0,12304 & 0,984 \\
\hline & 7-10 Y 11 & & & 0,06199 & 0,15787 & 0,979 \\
\hline Total & & 282 & 3,3979 & & & \\
\hline
\end{tabular}

${ }^{*} p<0,05$

Tablo 13. Mevcut sektörde çalışma süresi bakımından farklılık analizi

\begin{tabular}{llll}
\hline & $\begin{array}{l}\text { Mean Square (Gruplar } \\
\text { Arası) }\end{array}$ & f & Sig. (p) \\
\hline LMX & 1,178 & 1,322 & 0,268 \\
IAN & 0,475 & 0,383 & 0,765 \\
IST & 0,124 & 0,234 & 0,872 \\
PS & 0,191 & 0,955 & 0,414 \\
\hline
\end{tabular}

Altıncı demografik bilgi olan mevcut sektörde çalışma süresi verisinde farklılık analizi için SPSS programında One Way Anova analizi uygulanmıştır. Tablo 13'te mevcut sektörde çalışma süresi verilerine göre yapılan farklılık analizinin sonuçları görülmektedir. Lider üye etkileşimi, işten ayrılma niyeti, iş tatmini ve psikolojik sermaye değişkenlerine ait anlamlılık değerleri $(p>0,05)$ büyük olduğu için değişkenlerin mevcut sektörde çalışma süresi bakımından farklılaşmadığı sonucuna varılmıştır.

Tablo 14. Toplam çalışma süresi bakımından farklılık analizi

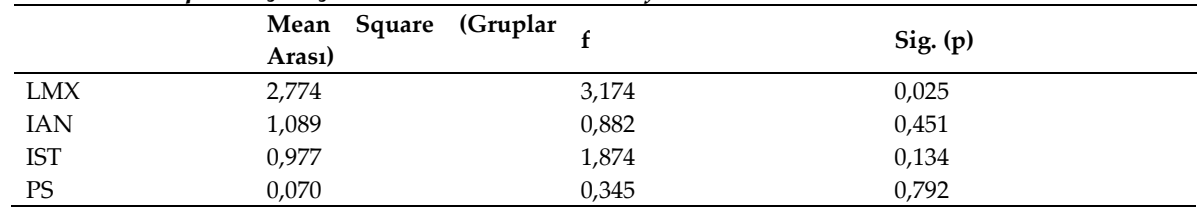


Yedinci ve son demografik bilgi olan toplam çalışma süresi verisinde farklılık analizi için SPSS programında One Way Anova analizi uygulanmıştır. Tablo 14'te toplam çalışma süresi verilerine göre yapılan farklılık analizinin sonuçları yer almaktadır. İşten ayrılma niyeti, iş tatmini ve psikolojik sermaye değişkenlerine ait anlamlılık değerleri $(p>0,05)$ büyük olması nedeniyle toplam çalışma süresi bakımından farklılaşmadığ 1 sonucuna varılmıştır. Ancak lider üye etkileşimi anlamlılık değeri $0,005,(p<0,05)$ olduğu için toplam çalışma süresi bakımından anlamlı bir şekilde farklılaşmaktadır. Bu sebeple toplam çalışma süresi bakımından farklılık analizinde lider üye etkileşimi için post-hoc Tukey testi gerçekleştirilmiştir.

Tablo 15. Lider üye etkileşiminde toplam çalışma süresi bakımından farklılık analizi

\begin{tabular}{|c|c|c|c|c|c|c|}
\hline $\begin{array}{l}\text { (I) Toplam Çalışma } \\
\text { Süresi }\end{array}$ & $\begin{array}{l}\text { (J) Toplam Çalışma } \\
\text { Süresi }\end{array}$ & $\mathbf{N}$ & Mean & Ort. Farklılığı (I-J) & $\begin{array}{l}\text { Std. } \\
\text { Hata }\end{array}$ & $\begin{array}{l}\text { Sig. } \\
\text { (p) }\end{array}$ \\
\hline & 3-6 Yil & & & 0,13485 & 0,29738 & 0,969 \\
\hline \multirow[t]{3}{*}{$0-2 Y_{1 l}$} & 7-10 Y 11 & 12 & 3,7986 & 0,33361 & 0,29240 & 0,664 \\
\hline & 11 ve üzeri & & & 0,52563 & 0,28082 & 0,243 \\
\hline & $0-2 Y_{11}$ & & & $-0,13485$ & 0,29738 & 0,969 \\
\hline \multirow[t]{3}{*}{ 3-6 Yil } & 7-10 Y 11 & 56 & 3,6637 & 0,19876 & 0,16815 & 0,639 \\
\hline & 11 ve üzeri & & & $0,39078^{*}$ & 0,14708 & 0,041 \\
\hline & $0-2 Y_{11}$ & & & $-0,33361$ & 0,29240 & 0,664 \\
\hline \multirow[t]{3}{*}{ 7-10 Yil } & 3-6 Yil & 69 & 3,4650 & $-0,19876$ & 0,16815 & 0,639 \\
\hline & 11 ve üzeri & & & 0,19202 & 0,13672 & 0,498 \\
\hline & $0-2 Y_{11}$ & & & $-0,52563$ & 0,28082 & 0,243 \\
\hline \multirow[t]{2}{*}{11 ve üzeri } & 3-6 Yil & 145 & 3,2730 & $-0,39078^{*}$ & 0,14708 & 0,041 \\
\hline & 7-10 Y 11 & & & $-0,19202$ & 0,13672 & 0,498 \\
\hline Total & & 282 & 3,4199 & & & \\
\hline
\end{tabular}

Lider üye etkileşiminde toplam çalışma süresi değişkeninde hangi alt gruplar arasında farklılaşma olduğu tablo 15'te gösterilmiştir. Yapılan Tukey testinde 3-6 yıl toplam çalışma süresi ile 11 ve üzeri toplam çalışma süresi gruplarında anlamlı bir farklılaşma olduğu görülmektedir $(\mathrm{p}<0,05)$. Bu durum 3-6 yıl toplam çalışma süresine sahip çalışanların, 11 ve üzeri toplam çalışma süresine sahip çalışanlara göre lider üye etkileşim düzeylerinin daha yüksek olduğunu ortaya koymaktadır. Diğer alt 
gruplarda yer alan toplam çalışma süreleri bakımından gruplar arasında farklılık olmadığı tespit edilmiştir $(p<0,05)$.

\section{Korelasyon ve Regresyon Analizleri}

Yapılmakta olan istatistiki değerlendirmelerin gerçek amacı konu değişkenler arasından bulunan ilişkinin varlığını ve düzeyini tespit etmektir. Birbirleri arasında etkileşim olan değişkenler arasında bulunan ilişkinin varlığı ve bu ilişkinin derecesi karar vericinin karar vermesini sağlayan en önemli unsurdur. Korelasyon analizi esas olarak, iki veya daha fazla değişkenin birbirleri ile olan ilişki dereceleri ve bu ilişkilerin yönünü belirlemektedir. Analize konu değişkenler arasındaki doğrusal ilişkinin gücü veya ilişkinin yönünü tespit eden korelasyon katsayısı " $r$ " olarak tanımlanmıştır. Değişkenler arasında yer alan ilişki aynı yönlü tam doğrusal ilişki ise $(\mathrm{r}=+1)$ zıt yönlü tam ilişki ise $(\mathrm{r}=-1)$ olarak gösterilmektedir (Tekin, 2009).

Tablo 16. Korelasyon analizi

\begin{tabular}{llllll}
\hline & $\begin{array}{l}\text { Lider } \\
\text { Etkileşimi }\end{array}$ & $\begin{array}{l}\text { Üye } \\
\text { Niyetisten }\end{array}$ & $\begin{array}{l}\text { Ayrılma } \\
\text { Nisçs Tatmini }\end{array}$ & $\begin{array}{l}\text { Psikolojik } \\
\text { Sermaye }\end{array}$ \\
\hline Lider Üye Etkileşimi & 1 & & & & \\
İşten Ayrılma Niyeti & $-0,467^{* *}$ & 1 & & \\
İş Tatmini & $0,576^{* *}$ & $-0,446^{* *}$ & 1 & 1 \\
Psikolojik Sermaye & $0,150^{*}$ & $-0,089$ & $0,323^{* *}$ & 1 \\
\hline$* *$ & & &
\end{tabular}

** $p<0.01{ }^{*} p<0.05$

Örneklem $(N)=282$

Pearson korelasyon analizi sonuçları tablo $16^{\prime}$ da gösterildiği gibidir. Lider üye etkileşimi ile işten ayrılma niyeti arasında olumsuz, orta düzeyde bir ilişki $(r=-0,467, p<0,01)$ bulunmaktadır. Buna göre lider-üye etkileşimi pozitif yönde artış gösterdiğinde işten ayrılma niyeti negatif yönde değişim gösterecektir. Lider-üye etkileşimi ile iş tatmini arasında pozitif ve orta düzeyde bir ilişki $(\mathrm{r}=0,576, \mathrm{p}<0,01)$ bulunmaktadır. Buna göre lider üye etkileşimi pozitif yönde artı̧ gösterdiğinde iş tatmini de pozitif yönde değişim gösterecektir. Lider üye etkileşimi ile psikolojik sermayenin arasında pozitif ve düşük düzeyde bir ilişki $(r=0,150, p<0,05)$ bulunmaktadır. Buna göre lider üye etkileşimi pozitif yönde artış gösterdiğinde psikolojik sermaye de pozitif yönde değişim gösterecektir. 
İşten ayrılma niyeti ile iş tatmini arasında negatif ve orta düzeyde bir ilişki $(\mathrm{r}=-0,446, \mathrm{p}<0,01)$ bulunmaktadır. Buna göre iş tatmini pozitif yönde artış gösterdiğinde işten ayrılma niyeti negatif yönde değişim gösterecektir. İşten ayrılma niyeti ile psikolojik sermaye arasında bir korelasyon ( $\mathrm{r}=-$ $0,089)$ tespit edilememiştir. İş tatmini ve psikolojik sermaye arasında pozitif ve orta düzeyde bir ilişki $(\mathrm{r}=0,323, \mathrm{p}<0,01)$ bulunmaktadır. Buna göre iş tatmini pozitif yönde artış gösterdiğinde psikolojik sermaye de pozitif yönde değişim gösterecektir.

Tablo 17. Alt boyutlar korelasyon analizi

\begin{tabular}{|c|c|c|c|c|c|c|c|c|c|c|}
\hline & LMXE & LMXV & LMXK & LMXP & IAN & IST & PSO & PSU & PSD & PSI \\
\hline LMXE & 1 & & & & & & & & & \\
\hline LMXV & $0,756^{* *}$ & 1 & & & & & & & & \\
\hline LMXK & $0,737^{* *}$ & $0,686^{* *}$ & 1 & & & & & & & \\
\hline LMXP & $0,783^{* *}$ & $0,652^{* *}$ & $0,687^{* *}$ & 1 & & & & & & \\
\hline IAN & $-0,437^{* *}$ & $-0,356^{* *}$ & $-0,423^{* *}$ & $-0,439^{* *}$ & 1 & & & & & \\
\hline IST & $0,519^{* *}$ & $0,473^{* *}$ & $0,540^{* *}$ & $0,516^{* *}$ & $-0,446^{* *}$ & 1 & & & & \\
\hline PSO & 0,036 & $-0,03$ & 0,074 & $-0,01$ & 0,039 & $0,172^{* *}$ & 1 & & & \\
\hline PSU & $0,252^{* *}$ & $0,129^{*}$ & $0,239^{* *}$ & $0,195^{* *}$ & $-0,169^{* *}$ & $0,341^{* *}$ & $0,651^{* *}$ & 1 & & \\
\hline PSD & 0,023 & 0,031 & 0,051 & $-0,02$ & 0,016 & $0,151^{*}$ & $0,483^{* *}$ & $0,481^{* *}$ & 1 & \\
\hline PSI & $0,200^{* *}$ & $0,119^{*}$ & $0,271^{* *}$ & $0,158^{* *}$ & $-0,169^{* *}$ & $0,354^{* *}$ & $0,383^{* *}$ & $0,552^{* *}$ & $0,414^{* *}$ & 1 \\
\hline
\end{tabular}

${ }^{* *} p<0.01{ }^{*} p<0.05$

Örneklem $(N)=282$

Lider-üye etkileşimi ve psikolojik sermaye değişkenlerinin sahip olduğu alt boyutları ile yapılan korelasyon analizi tablo 17' de gösterildiğ $i$ gibidir. Lider üye etkileşimi etki alt boyutu ile işten ayrılma niyeti arasında negatif ve orta düzeyde bir ilişki $(\mathrm{r}=-0,437, \mathrm{p}<0,01)$ bulunmaktadır. Buna göre lider-üye etkileşimi etki alt boyutu pozitif yönde artış gösterdiğinde işten ayrılma niyeti negatif yönde değişim gösterecektir. Lider üye etkileşimi etki alt boyutu ile iş tatmini arasında pozitif ve orta düzeyde bir ilişki $(\mathrm{r}=0,519, \mathrm{p}<0,01)$ bulunmaktadır. Buna göre lider üye etkileşimi etki alt boyutu pozitif yönde artış gösterdiğinde iş tatmini de pozitif yönde değişim gösterecektir. Lider-üye etkileşimi etki alt boyutu ile psikolojik sermaye öz yeterlilik alt boyutu arasında anlamlı bir korelasyon $(\mathrm{r}=0,036)$ tespit edilememiştir. Lider üye etkileşimi etki alt boyutu ile psikolojik sermaye umut alt boyutu arasında pozitif ve düşük düzeyde bir ilişki $(\mathrm{r}=0,252, \mathrm{p}<0,01)$ bulunmaktadır. Buna göre lider üye etkileşimi etki alt boyutu pozitif yönde artış gösterdiğinde psikolojik sermaye umut alt boyutu da pozitif yönde değişim gösterecektir. Lider 
üye etkileşimi etki alt boyutu ile psikolojik sermaye dayanıklılık alt boyutu arasında anlamlı bir korelasyon $(\mathrm{r}=0,023)$ tespit edilememiştir. Lider üye etkileşimi etki alt boyutu ile psikolojik sermaye iyimserlik alt boyutu arasında pozitif ve düşük düzeyde bir ilişki $(r=0,200, p<0,01)$ bulunmaktadır. Buna göre lider üye etkileşimi etki alt boyutu pozitif yönde artış gösterdiğinde psikolojik sermaye iyimserlik alt boyutu da pozitif yönde değişim gösterecektir. Lider üye etkileşimi vefakârlık alt boyutu ile işten ayrılma niyeti arasında negatif ve orta düzeyde bir ilişki $(\mathrm{r}=-0,356, \mathrm{p}<0,01)$ bulunmaktadır. Buna göre lider üye etkileşimi vefakârlık alt boyutu pozitif yönde artış gösterdiğinde işten ayrılma niyeti negatif yönde değişim gösterecektir. Lider üye etkileşimi vefakârlık alt boyutu ile iş tatmini arasında pozitif yönlü, orta düzeyde ve anlamlı ilişki $(\mathrm{r}=0,473, \mathrm{p}<0,01)$ bulunmaktadır. Buna göre lider üye etkileşimi vefakârlık alt boyutu pozitif yönde artış gösterdiğinde iş tatmini de pozitif yönde değişim gösterecektir. Lider üye etkileşimi vefakarlık alt boyutu ile psikolojik sermaye öz yeterlilik alt boyutu arasında anlamlı bir korelasyon $(\mathrm{r}=-0,03)$ tespit edilememiştir. Lider üye etkileşimi vefakârlık alt boyutu ile psikolojik sermaye umut alt boyutu arasında pozitif yönlü, düşük düzeyde ve anlamlı ilişki $(r=0,129, p<0,01)$ bulunmaktadır. Buna göre lider üye etkileşimi vefakârlık alt boyutu pozitif yönde artış gösterdiğinde psikolojik sermaye umut alt boyutu da pozitif yönde değişim gösterecektir. Lider üye etkileşimi vefakarlık alt boyutu ile psikolojik sermaye dayanıklılık alt boyutu arasında anlamlı bir korelasyon $(\mathrm{r}=0,031)$ tespit edilememiştir. Lider üye etkileşimi vefakârlık alt boyutu ile psikolojik sermaye iyimserlik alt boyutu arasında pozitif ve düşük düzeyde bir ilişki $(r=0,119, p<0,01)$ bulunmaktadır. Buna göre lider üye etkileşimi vefakârlık alt boyutu pozitif yönde artış gösterdiğinde psikolojik sermaye iyimserlik alt boyutu da pozitif yönde değişim gösterecektir. Lider üye etkileşimi katkı alt boyutu ile işten ayrılma niyeti arasında negatif ve orta düzeyde bir ilişki $(\mathrm{r}=-0,423, \mathrm{p}<0,01)$ bulunmaktadır. Buna göre lider üye etkileşimi katkı alt boyutu pozitif yönde artış gösterdiğinde işten ayrılma niyeti negatif yönde değişim gösterecektir. Lider üye etkileşimi katkı alt boyutu ile iş tatmini arasında pozitif ve orta düzeyde bir ilişki $(\mathrm{r}=0,540, \mathrm{p}<0,01)$ bulunmaktadır. Buna göre lider üye etkileşimi katkı alt boyutu pozitif yönde artış gösterdiğinde iş tatmini de pozitif yönde değişim gösterecektir. Lider üye etkileşimi 
katkı alt boyutu ile psikolojik sermaye öz yeterlilik alt boyutu arasında anlamlı bir korelasyon $(\mathrm{r}=0,074)$ tespit edilememiştir. Lider üye etkileşimi katkı alt boyutu ile psikolojik sermaye umut alt boyutu arasında pozitif ve düşük düzeyde ilişki $(\mathrm{r}=0,239, \mathrm{p}<0,01)$ bulunmaktadır. Buna göre lider üye etkileşimi katkı alt boyutu pozitif yönde artış gösterdiğinde psikolojik sermaye umut alt boyutu da pozitif yönde değişim gösterecektir. Lider üye etkileşimi katkı alt boyutu ile psikolojik sermaye dayanıklılık alt boyutu arasında anlamlı bir korelasyon $(\mathrm{r}=, 051)$ tespit edilememiştir. Lider üye etkileşimi katkı alt boyutu ile psikolojik sermaye iyimserlik alt boyutu arasında pozitif ve düşük düzeyde bir ilişki $(\mathrm{r}=0,271, \mathrm{p}<0,01)$ bulunmaktadır. Buna göre lider üye etkileşimi katkı alt boyutu pozitif yönde artış gösterdiğinde psikolojik sermaye iyimserlik alt boyutu da pozitif yönde değişim gösterecektir. Lider üye etkileşimi profesyonel sayg1 alt boyutu ile işten ayrılma niyeti arasında negatif ve orta düzeyde bir ilişki $(r=-0,439, p<0,01)$ bulunmaktadır. Buna göre lider üye etkileşimi profesyonel saygı alt boyutu pozitif yönde artış gösterdiğinde işten ayrılma niyeti negatif yönde değişim gösterecektir. Lider üye etkileşimi profesyonel saygı alt boyutu ile iş tatmini arasında pozitif ve orta düzeyde ilişki $(\mathrm{r}=0,516, \mathrm{p}<0,01)$ bulunmaktadır. Buna göre lider üye etkileşimi profesyonel saygı alt boyutu pozitif yönde artış gösterdiğinde iş tatmini de pozitif yönde değişim gösterecektir. Lider üye etkileşimi profesyonel sayg1 alt boyutu ile psikolojik sermaye öz yeterlilik alt boyutu arasında anlamlı bir korelasyon $(\mathrm{r}=-0,01)$ tespit edilememiştir. Lider üye etkileşimi profesyonel saygi alt boyutu ile psikolojik sermaye umut alt boyutu arasında pozitif ve düşük düzeyde bir ilişki $(\mathrm{r}=0,195, \mathrm{p}<0,01)$ bulunmaktadır. Buna göre lider üye etkileşimi profesyonel saygı alt boyutu pozitif yönde artış gösterdiğinde psikolojik sermaye umut alt boyutu da pozitif yönde değişim gösterecektir. Lider üye etkileşimi profesyonel sayg 1 alt boyutu ile psikolojik sermaye dayanıklılık alt boyutu arasında anlamlı bir korelasyon $(\mathrm{r}=-0,02)$ tespit edilememiştir. Lider üye etkileşimi profesyonel saygı alt boyutu ile psikolojik sermaye iyimserlik alt boyutu arasında pozitif ve düşük düzeyde bir ilişki $(r=0,158, p<0,01)$ bulunmaktadır. Buna göre lider üye etkileşimi profesyonel saygı alt boyutu pozitif yönde artış gösterdiğinde psikolojik sermaye iyimserlik alt boyutu da pozitif yönde değişim gösterecektir. 
İşten ayrılma niyeti ile psikolojik sermaye öz yeterlilik alt boyutu arasında anlamlı bir korelasyon $(r=0,039)$ tespit edilememiştir. İşten ayrılma niyeti ile psikolojik sermaye umut alt boyutu arasında negatif ve düşük düzeyde bir ilişki $(\mathrm{r}=-0,169, \mathrm{p}<0,01)$ bulunmaktadır. Buna göre işten ayrılma niyeti pozitif yönde artış gösterdiğinde psikolojik sermaye umut alt boyutu negatif yönde değişim gösterecektir. İşten ayrılma niyeti ile psikolojik sermaye dayanıklılık alt boyutu arasinda anlamlı bir korelasyon $(r=0,016)$ tespit edilememiştir. İşten ayrılma niyeti ile psikolojik sermaye iyimserlik alt boyutu arasında negatif ve düşük düzeyde bir ilişki $(r=-0,169, p<0,01)$ bulunmaktadır. Buna göre işten ayrılma niyeti pozitif yönde artış gösterdiğinde psikolojik sermaye iyimserlik alt boyutu negatif yönde değişim gösterecektir.

İş tatmini ile psikolojik sermaye öz yeterlilik alt boyutu arasında pozitif ve düşük düzeyde bir ilişki $(r=0,172)$ bulunmaktadır. Buna göre iş tatmini pozitif yönde artış gösterdiğinde psikolojik sermaye öz yeterlilik alt boyutu da pozitif yönde değişim gösterecektir. İş tatmini ile psikolojik sermaye umut alt boyutu arasında pozitif ve orta düzeyde ilişki $(r=0,341)$ bulunmaktadır. Buna göre iş tatmini pozitif yönde artış gösterdiğinde psikolojik sermaye umut alt boyutu da pozitif yönde değişim gösterecektir. İş tatmini ile psikolojik sermaye dayanıklılık alt boyutu arasında pozitif ve düşük düzeyde bir ilişki $(r=0,151)$ bulunmaktadır. Buna göre iş tatmini pozitif yönde artış gösterdiğinde psikolojik sermaye dayanıklılık alt boyutu da pozitif yönde değişim gösterecektir. İş tatmini ile psikolojik sermaye iyimserlik alt boyutu arasında pozitif ve orta düzeyde bir ilişki $(r=0,354)$ bulunmaktadır. Buna göre iş tatmini pozitif yönde artış gösterdiğinde psikolojik sermaye iyimserlik alt boyutu da pozitif yönde değişim gösterecektir.

Tablo 18. Lider üye etkileşiminin iş tatminine etkisine ilişkin regresyon analizi

\begin{tabular}{|c|c|c|c|c|c|c|c|c|}
\hline & \multicolumn{2}{|c|}{$\begin{array}{l}\text { Standart Olmayan } \\
\text { Katsayilar }\end{array}$} & \multirow{2}{*}{$\begin{array}{l}\begin{array}{l}\text { Standart } \\
\text { Katsayılar }\end{array} \\
\text { Beta }\end{array}$} & \multirow[b]{2}{*}{$t$} & \multirow[b]{2}{*}{$\mathrm{p}$} & \multirow[b]{2}{*}{$\mathbf{R}^{2}$} & \multirow[b]{2}{*}{$\mathbf{f}$} & \multirow[b]{2}{*}{$\mathbf{p}$} \\
\hline & B & Std. Hata & & & & & & \\
\hline Sabit & 1,886 & 0,133 & & 14,187 & 0,000 & 0,33 & 139,34 & 0,000 \\
\hline LMX & 0,442 & 0,037 & 0,576 & 11,804 & 0,000 & & & \\
\hline
\end{tabular}

Lider-üye etkileşiminin iş tatminine etkisinin olup olmadığını, varsa ne derecede etkilediğini tespit edebilmek için uygulanan regresyon analizi 
sonuçları tablo 18 'de gösterilmiştir. Oluşturulan bu modelin regresyon sonuçları incelendiğinde, istatistiki olarak anlamlı olduğu ve lider üye etkileşiminin iş tatmini değişkeninin varyansının \%33'ünü açıklanabilir kıldı̆̆1 görülebilmektedir ( $R 2=0,33 ; \mathrm{F}=139,34 ; \mathrm{p}<0,01)$. Tüm bu sonuçlara göre lider üye etkileşiminin iş tatmini etkilediği ifade edilebilmektedir.

Tablo 19. Lider üye etkileşiminin işten ayrulma niyeti üzerindeki etkisine ilişkin regresyon analizi

\begin{tabular}{|c|c|c|c|c|c|c|c|c|}
\hline & \multicolumn{2}{|c|}{$\begin{array}{l}\text { Standart Olmayan } \\
\text { Katsayılar }\end{array}$} & \multirow{2}{*}{$\begin{array}{l}\begin{array}{l}\text { Standart } \\
\text { Katsayilar }\end{array} \\
\text { Beta } \\
\end{array}$} & \multirow[b]{2}{*}{$\mathbf{t}$} & \multirow[b]{2}{*}{$\mathrm{p}$} & \multirow[b]{2}{*}{$\mathbf{R}^{2}$} & \multirow[b]{2}{*}{$\mathrm{f}$} & \multirow[b]{2}{*}{$\mathrm{p}$} \\
\hline & B & Std. Hata & & & & & & \\
\hline Sabit & 4,512 & 0,22 & & 20,488 & 0,000 & 0,22 & 77,979 & 0,000 \\
\hline LMX & $-0,548$ & 0,062 & $-0,467$ & $-8,831$ & 0,000 & & & \\
\hline
\end{tabular}

Lider-üye etkileşiminin işten ayrılma niyetine etkisini tespit edebilmek için uygulanan regresyon analizi sonuçları tablo 19'da gösterilmiştir. Oluşturulan bu modelin regresyon sonuçları incelendiğinde, istatistiki olarak lider üye etkileşiminin işten ayrılma niyeti değişkeninindeki varyansın \%22'sini açıkladığ1 görülebilmektedir ( $\mathrm{R} 2=0,22 ; \mathrm{F}=77,979$; $\mathrm{p}<0,01)$. Dolayısıyla lider-üye etkileşiminin işten ayrılma niyetini etkilemektedir.

\section{Düzenleyici Etki Analizi}

Lider üye etkileşiminin işten ayrılma niyetine etkisinde psikolojik sermayenin düzenleyici rolünün etkisini tespit edebilmek için yapılan düzenleyici analizi SPSS Hayes Process uygulaması ile gerçekleştirilmiştir (Hayes, 2018).

Tablo 20. Lider üye etkileşimi, işten ayrulma niyeti ve psikolojik sermaye düzenleyici analizi

\begin{tabular}{|c|c|c|c|c|c|c|}
\hline \multicolumn{7}{|c|}{ Model Özeti } \\
\hline $\mathbf{R}$ & $\mathbf{R}^{2}$ & MSE & $\mathbf{F}$ & df1 & df2 & $\mathrm{p}$ \\
\hline 0,4819 & 0,2322 & 0,9570 & 28,0301 & 3,0000 & 278,0000 & 0,0000 \\
\hline Model & Katsayı & se & $\mathbf{t}$ & p & LLCI & ULCI \\
\hline Sabit & 1,0117 & 1,7136 & 0,5904 & 0,5554 & $-2,3616$ & 4,3850 \\
\hline LMX & 0,6063 & 0,5140 & 1,1795 & 0,2392 & $-0,4056$ & 1,6182 \\
\hline PS & 0,8623 & 0,4241 & 2,0332 & 0,0430 & 0,0274 & 1,6972 \\
\hline Int_1 & $-0,2841$ & 0,1259 & $-2,2559$ & 0,0249 & $-0,5320$ & $-0,0362$ \\
\hline
\end{tabular}


Tablo 20'de etkileşim satırı (Int_1) incelendiğinde, lider üye etkileşiminin işten ayrılma niyetine etkisinde psikolojik sermayenin düzenleyici etkisi olduğu görülmektedir $(\mathrm{p}=0,0249, \mathrm{p}<0,05)$.

Tablo 21. Düzenleyici etki analizi değerler tablosu

\begin{tabular}{lllllll}
\hline PS & Katsay1 & se & $\mathbf{t}$ & $\mathbf{p}$ & LLCI & ULCI \\
\hline 3,4876 & $-0,3846$ & 0,0945 & $-4,0674$ & 0,0001 & $-0,5705$ & $-0,1984$ \\
3,9352 & $-0,5117$ & 0,0641 & $-7,9806$ & 0,0000 & $-0,6379$ & $-0,3855$ \\
4,3827 & $-0,6389$ & 0,0751 & $-8,5088$ & 0,0000 & $-0,7867$ & $-0,4911$ \\
\hline
\end{tabular}

Tablo 21'de psikolojik sermayenin alt, orta ve üst düzey durumunda etkileri incelenebilmektedir. Psikolojik sermaye düzeyi alt seviyede olduğunda, lider üye etkileşimi ile işten ayrılma niyeti arasında 0,3846 etki seviyesinde olumsuz bir ilişki olduğu görülmektedir. Sonuç olarak düşük düzeyde psikolojik sermaye, lider üye etkileşimi ile işten ayrılma niyeti arasındaki ilişki için negatif ve $\% 38$ düzeylerinde bir etkiye sahip olduğu yorumlanabilir. Psikolojik sermaye düzeyi orta seviyede olduğunda, lider üye etkileşimi ile işten ayrılma niyeti arasında 0,5117 etki seviyesinde negatif ve anlamlı bir ilişki olduğu görülmektedir. Sonuç olarak orta düzeyde psikolojik sermaye, lider üye etkileşimi ile işten ayrılma niyeti arasındaki ilişki için negatif ve \%51 düzeylerinde bir etkiye sahip olduğu şeklinde yorumlanabilir. Psikolojik sermaye düzeyi üst seviyede olduğunda, lider üye etkileşimi ile işten ayrılma niyeti arasında 0,6389 etki seviyesinde negatif yönlü anlamlı bir ilişki olduğu görülmektedir. Sonuç olarak psikolojik sermaye, lider üye etkileşimi ile işten ayrılma niyeti arasındaki ilişki için negatif ve \%64 düzeylerinde bir etkiye sahiptir.

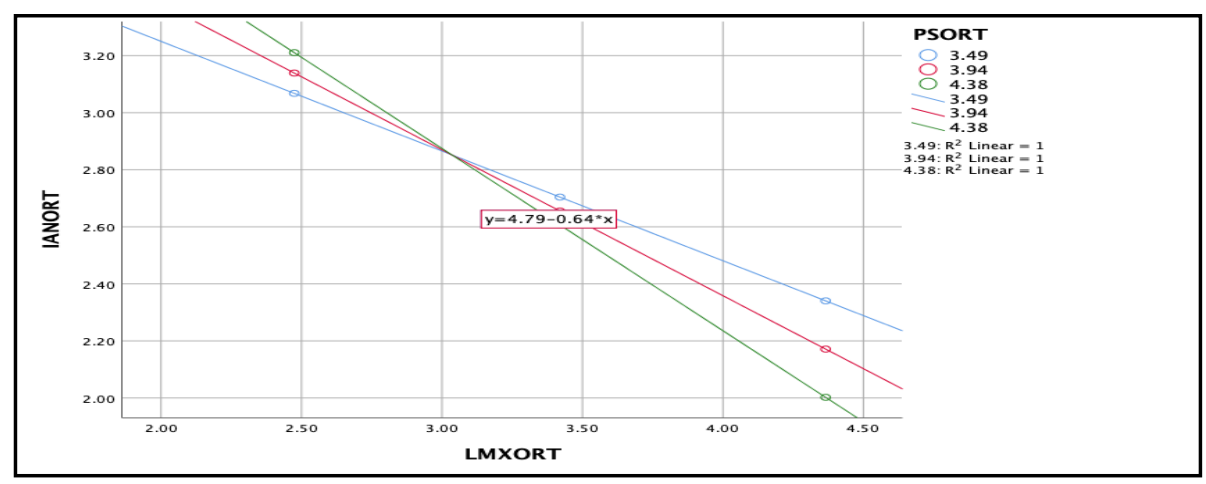

Şekil 2. Düzenleyici etki grafiği 
Tablo 21' de yer alan veriler eşliğinde oluşan, psikolojik sermayenin alt, orta ve üst düzey seviyelerini gösteren düzenleyici etki grafiği şekil 2'de gösterilmiştir.

Lider üye etkileşiminin iş tatminine etkisinde psikolojik sermayenin düzenleyici rolünün etkisini tespit edebilmek için yapılan düzenleyici analizi SPSS Hayes Process uygulaması ile gerçekleştirilmiştir (Hayes, 2018).

Tablo 22. Lider üye etkileşimi, iş tatmini ve psikolojik sermaye düzenleyici analizi

\begin{tabular}{lllllll}
\hline \multicolumn{2}{l}{ Model Özeti } \\
$\mathbf{R}$ & $\mathbf{R}^{\mathbf{2}}$ & $\mathbf{M S E}$ & $\mathbf{F}$ & $\mathbf{d f 1}$ & $\mathbf{d f 2}$ & $\mathbf{p}$ \\
\hline 0,6277 & 0,3940 & 0,3224 & 60,2453 & 3,0000 & 278,0000 & 0,0000 \\
Model & Katsayı & se & $\mathbf{t}$ & $\mathbf{p}$ & LLCI & ULCI \\
\hline Sabit & 1,8260 & 0,9945 & 1,8361 & 0,0674 & $-0,1317$ & 3,7838 \\
LMX & $-0,0199$ & 0,2983 & $-0,0667$ & 0,9469 & $-0,6072$ & 0,5674 \\
PS & 0,0485 & 0,2461 & 0,1969 & 0,8441 & $-0,4361$ & 0,5330 \\
Int_1 & 0,1072 & 0,0731 & 1,4664 & 0,1437 & $-0,0367$ & 0,2511 \\
\hline
\end{tabular}

Tablo 22'te etkileşim satırı (Int_1) incelendiğinde, lider üye etkileşiminin iş tatminine etkisinde psikolojik sermayenin düzenleyici etkisi olmadığı görülmektedir ( $\mathrm{p}=0,1437, \mathrm{p}<0,05)$.

\section{Tablo 23. Hipotezler ve analizler}

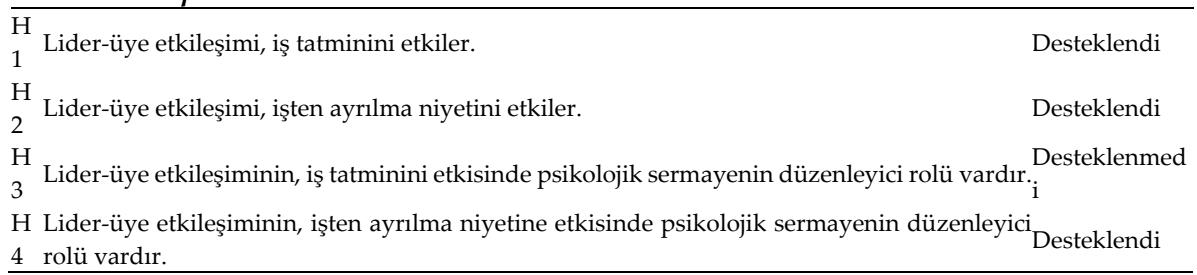

Yapılan araştırma ve analiz sonuçlarına göre tablo 23'te görüldüğü gibi, hipotezlerin üç tanesi desteklenmiş, bir tanesi desteklenmemiştir.

\section{Sonuç}

Yapılmış olan literatür taraması, araştırma ve analizler birlikte değerlendirilmiş olup lider-üye etkileşiminin iş tatmini ve işten ayrılma niyetine etkisinde psikolojik sermayenin düzenleyici rolü incelenmiştir. Çalışmada öncelikli olarak İstanbul ili finans sektörü değerlendirilmiş, 
daha sonra sektör sınırı olmaksızın araştırma genişletilmiş ve finans sektörü ile diğer sektörler arasında lider üye etkileşiminin iş tatmini ve işten ayrılma niyetine etkisinde psikolojik sermayenin düzenleyici rolü açısından ve alt gruplar düzeyinde bir farklılık olup olmadığ değerlendirilmiştir.

Lider-üye etkileşimi ile ilgili yazınlar lider-üye etkileşiminin üst seviyede olduğu durumların, astın daha çok iş tatmini hissetmesi ve daha nitelikli iş performansı sergilemesi, astın üstün aldığı kararları daha çok etkilemesi ve daha az iş gören devri ile sonuçlandığını ifade etmektedir (Gerstner ve Day, 1997; Sparrowe ve Liden, 1997; Vecchio ve Gobdel, 1984; Liden ve Graen, 1980). Yapılmış olan bu araştırma ve incelemeler neticesinde işten ayrılma niyeti ve iş tatmini kavramlarının birçok farklı değişkene bağlı olduğu görülmüştür. Bu iki kavramın örgüt için etkisi bu kadar önemli iken bu kavramları etkileyen faktörlerin tespiti de oldukça önemlidir.

Analiz çalışmaları sonucunda görülmüştür ki lider üye etkileşim düzeyi iş tatmini ve işten ayrılma niyetini etkilemektedir. Bu durum ilk iki hipotezi doğrulamaktadır. Ayrıca lider üye etkileşiminin işten ayrılma niyeti üzerindeki etkisinde psikolojik sermayenin düzenleyici rolü olduğu hipotezi de yapılan çalışmalar ile desteklenmiş ve doğrulanmıştır. Ancak lider üye etkileşimin iş tatmini üzerindeki rolünde psikolojik sermayenin bir düzenleyici rolünün olmadığı yapılan çalışma ile desteklenememiş ve doğrulanmamıştır.

Daha önce de belirtildiği gibi araştırma hem finans sektörü özelinde hem de bu sınır olmadan yapılmıştır. Finans sektörü özelinde sadece lider üye etkileşim düzeyinin daha yüksek olduğu tespit edilmiştir. Ancak diğer değişkenler için herhangi bir farklılık ortaya çıkmamıştır. Ayrıca yapılmış olan çalışmalar ve analizler ortaya koymuştur ki demografik olarak örneklemin çoğunluğu oluşturan "26-35" ile "36-45" yaş grupları arasında lider üye etkileşiminde anlamlı bir farklılık tespit edilmiştir. Daha genç olan "26-35" yaş arası grubu lider üye etkileşim düzeyi daha yüksektir. Bu da göstermektedir ki lider üye etkileşiminin önemi örgütler için gün geçtikte daha da artacaktır.

Yapılan demografik değerlendirmelerde bir diğer önemli tespit ise mevcut çalışılan firmadaki çalışma süresi "0-2 yıl" ile "3-6 yıl” arasında olanlarda tespit edilmiştir. Görülmüştür ki işe yeni başlayan çalışanların 
lider üye etkileşim düzeyi daha yüksektir. Bunu destekler şekilde toplam çalışma süresi arttıkça lider üye etkileşim düzeyi azalmaktadır.

Mevcut piyasa koşullarında insan kaynağını etkin kullanmak, personel devir oranını düşürmek ve nitelikli iş gücünü elde tutmak oldukça önemlidir. Firmaların yeni başlayan personel için yaptığ1 yatırım, eğitim ve oryantasyon süreçleri için harcanan zamanda düşünüldüğünde iş veren için her yeni başlayan personel bir yük getirmektedir. Bununla birlikte çoğu durumda yetişmiş personelin işveren için yeni başlayan bir personelden örgüt için daha etkili olduğu açıktır. Bu nedenle mevcut piyasa koşullarında firmalar en iyi personeli bulmaya odaklandıkları gibi bir diğer yanda da yetişmiş personeli ellerinde tutmak için çaba sarf etmektedirler. Lider ve üye arasındaki etkileşimin işten ayrılma niyeti ve iş tatminini ne ölçüde etkilediği işverenin politikalarını belirlemek adına oldukça önemlidir. Çünkü bu sürecin en başında tespit edilebilecek bir unsurdur. Günümüzde kurumsal firmalar işe alım süreçlerinde personelin kişilik envanterini profesyonel süreçlerden geçirerek tespit etmektedirler. Psikolojik sermaye de sabit bir değer taşımamakla beraber eğitim ile geliştirilebilinen, olumlu, bireysel, kavramsal ve ölçülebilir bir olgudur (Luthans ve diğ., 2006). Bu nedenle işe alım süreçleri kişinin psikolojik sermayesini ölçecek şekilde kurgulanmasında fayda vardır. Bu sayede çalışan ve yönetici arasındaki olumlu veya olumsuz etkileşimin çalışanın performansının düşmesine sebep olup olmayacağını, işten ayrılma niyetinin olumsuz yönde etkilenip etkilenmeyeceği önceden tahmin etmek mümkün olabilecektir. Dolayısıyla kurum içi eğitimler ile üyenin psikolojik sermayesi pozitif yönde desteklenmesi gibi politikalarla örgüt için faydalı sonuçlara üretilebilir.

Tüm bu tespit ve bulgulardan hareketle işten ayrilma niyeti ve iş tatmininin verimlilik üzerine etkisi olabileceği değerlendirilmektedir. Bu çalışmada, lider üye etkileşiminin iş tatmini ve işten ayrılma niyetine etkisi ve psikolojik sermayenin bu ilişkideki düzenleyici rolünün incelenmesinin alana olumlu bir katkı yapacağı değerlendirilmiştir. Ayrıca gelecek araştırmacıların bu değişkenlerin verimlilik üzerine etkilerinin birlikte ele alındığı çalışmalar yapmasının hem literatüre hem de sektöre katkı sağlayacağı düşünülmektedir. 
EXTENDED ABSTRACT

\title{
The Moderator Role of the Psychological Capital in the Effect of Leader-Member Exchange On Job Satisfaction and Intention to Leave
}

\author{
Yasemin Büyükkaymakcı- Mustafa Sundu \\ Istinye University
}

Traditional leadership approaches are no longer sufficient to explain the relations between the leader and the subordinates. Today, the traditional point of view that emotions have no place in business is losing its importance. Most leadership approaches focus on which behavior is right for the leader to choose when confronting his followers with various situational variables. Regardless from situation it is assumed that the leader behaves the same for all followers (Liden and Graen 1980). However, Leader-Member Exchange theory clearly reveals the that leaders do not equally interact with all group members in the group (Liden and Maslyn 1998; Scandura et al. 1986). The literature on leadermember exchange reveals the importance of quality of leader-member relationships in organizations. It has been determined that a qualified leader-member exchange provides more encouragement and more job satisfaction to the subordinate. These good feelings lead more qualified job performance and less employee turnover (Gerstner and Day 1997; Sparrowe and Liden 1997; Vecchio and Gobdel 1984; Liden and Graen 1980). On the other hand, members with low levels of interaction with their leaders have access to fewer resources and limited information. As a result, these negativities potentially lead to job dissatisfaction, reduce organizational commitment, and increase intention to leave (Maslyn and Uhl-Bien 2001). Liden and Maslyn (1998), suggested that the leadermember exchange should be multidimensional, and they revealed four dimensions as impact, contribution, professional respect, and loyalty.

The leader is the person who ensures the adoption of common ideas and goals by the members of the group, and who directs and develops the positive characteristics of the members within the framework of this purpose. The leader-member exchange theory is based on the 
understanding that the leader establishes different relationships with each of the members, according to the needs of them. Another concept that can be effective in this relationship is the level of psychological capital that individuals have. Psychological capital refers to the positive psychological state of the individual and consists of four main components. These components are self-efficacy, hope, optimism, and resilience.

In this study, it is examined whether the leader member exchange has an impact on the intention to leave and job satisfaction, on the other hand, it is examined whether the psychological capital level of the employee has a moderator role in this relation. Additionally, it is also examined whether all these variables differed demographically or not. Therefore, following research hypotheses is developed.

H1. Leader member exchange affects job satisfaction.

H2. Leader member exchange affects turnover intention.

H3. Psychological capital has a moderator role in the effect of leader member exchange on job satisfaction.

H4 Psychological capital has a moderator role in the effect of leader member exchange on turnover intention.

The research is conducted on a sample selected both from the financial sector and other sectors to make comparisons. The findings of the analysis based on the data obtained show that leader member change affects job satisfaction and intention to leave. This confirms the first two hypotheses. In addition, the hypothesis that psychological capital has a moderator role in the effect of leader member exchange on turnover intention was supported and confirmed. However, it was revealed that psychological capital did not have a moderator role in the effect of leader member exchange on job satisfaction.

It has been determined that only the leader member exchange level is higher in the finance sector. However, there was no difference for other variables. In addition, findings revealed that there is a significant difference in leader member exchange level between the 26-35 and 36-45 age groups. The younger group between the ages of 26-35 has a higher level of leader member exchange. This indicates that the importance of leader member exchange will increase day by day for organizations. Another important finding is that leader-member exchange level of members with 0-2 years working experience in the current company is 
higher than those with 3-6 years working experience in the current company. Similarly with these findings, the level of leader member exchange decreases as the total work experience increases. In the current market conditions, it is very important to use human resources effectively, to reduce turnover rates and to retain qualified workforce.

Each new personnel bring a burden for the employer considering the cost and the time spent on training and orientation processes. However, in most cases, trained personnel are more effective for the employer than a new employee for the organization. In the current market conditions, companies focus on finding the best personnel, on the other hand, they strive to retain trained and experienced personnel. For this reason, it is very important to know that the leader-member exchange level and the psychological capital level positively affect the intention to leave and job satisfaction to determine human resources policies. Especially individual psychological capital can be measured in the recruitment process. Currently, organizations determine the personality inventory of the candidates in their recruitment processes. So psychological capital measurement can be part of this recruitment inquiries. With in-house training, the psychological capital of the employees can be positively supported, and benefits for the organization can be achieved. From this perspective findings of this study contribute to human resource management process.

\section{Kaynakça / References}

Agin, Ö. (2010). İşe bağlanma düzeyinin işten ayrllma niyeti üzerine etkileri. Yüksek Lisans Tezi. Kocaeli Üniversitesi, SBE, Kocaeli.

Akgündüz, Y., Akdağ, G., Güler, O. ve Sünnetçioğlu, S. (2014). İşten ayrılma niyeti ve aşırı rol yükünün otel çalışanlarının sosyal aylaklık davranışlarına etkisi. Dokuz Eylül Üniversitesi Sosyal Bilimler Enstitüsü Dergisi, 16(4), 515-536.

Arslantaş, C. C. (2007). Dönüşümcü liderliğin psikolojik güçlendirme ve örgütsel vatandaşlık davranışı üzerindeki etkisi. Amme İdaresi Dergisi, 40(4), 81-101.

Bandura, A. (1977). Self-efficacy: Toward a unifying theory of behavioral change. Psychological Review, 84(2), 191-215. 
Bandura, A. (1982). Self-efficacy mechanism in human agency. American Psychologist, 37(2), 122-147.

Bandura, A. (1993). Perceived self-efficacy in cognitive development and functioning. Educational Psychologist, 28(2), 117-148.

Baş, T., Keskin, N. ve Mert, İ. S. (2010). Lider üye etkileşimi (lüe) modeli ve ölçme aracının türkçe de geçerlik ve güvenilirlik analizi. Ege Akademik Bakis (Ege Academic Review), 10(3), 1013-1039.

Bingöl, D. (2001). İşletmelerde davranış. İstanbul: Beta.

Clugston, M. (2000). The mediating effects of multidimensional commitment on job satisfaction and intent to leave. Journal of Organizational Behavior, 21(4), 477-486.

Çelik Keleş, H. N. (2006). İş tatminin örgütsel bağlllık üzerindeki etkisine ilişkin ilaç üretim ve dağıtım firmalarında yapılan bir araştırma. Doktora Tezi. Selçuk Üniversitesi, SBE, Konya.

Dattalo, P. (2008). Determining sample size: Balancing power, precision, and practicality. Oxford University Press.

Dienesch, R. M. and Liden, R. C. (1986). Leader-member exchange model of leadership: A critique and further development. Academy of Management Review, 11(3), 618-634.

Elmas, N. (2017). Örgütsel iletişim ve iş tatmini arasındaki ilişki. İstanbul Ticaret Üniversitesi Dış Ticaret Enstitüsü Working Paper Series.

Eren, E. (1991). Yönetim ve organizasyon. İstanbul: İ.Ü. İşletme Fakültesi Yayınları.

Eren, E. (2001). Yönetim ve organizasyon - çağdaş ve küresel yaklaşımlar. İstanbul: Beta.

Erkuş, A. ve Fındıklı, M. A. (2013). Psikolojik sermayenin iş tatmini, iş performansı ve işten ayrılma niyeti üzerindeki etkisine yönelik bir araştırma. İstanbul Üniversitesi İşletme Fakültesi Dergisi, 42(2), 302-318.

Gerstner, C. R. and Day, D. D. (1997). Meta-analytic review of leader-member exchange theory: correlates and construct issues. Journal of Applied Psychology, 82(6), 827-844.

Greguras, G. J. and Ford, J. M. (2006). An examination of the multidimensionality of supervisor and subordinate perceptions of leader-member exchange. Journal of Occupational and Organizational Psychology, 79, 433-465. 
Hayes, Andrew F. 2018. Introduction to Mediation, Moderation, and Conditional Process Analysis: A Regression-Based Approach. Second. ed. Todd D. Little.

Jarden, A. (2012). Positive psychologists on positive psychology: Ilona boniwell. International Journal of Wellbeing, 2(2), 119-124.

Kim, S. S., Im, J. and Hwang, J. (2015). The effects of mentoring on role stress, job attitude and turnover intention in the hotel industry. International Journal of Hospitality Management, 48, 68-82.

Liden, R. C. and Graen, G. (1980). Generalizability of the vertical dyad linkage model of leadership. Academy of Management Journal, 23(3), 451-465.

Liden, R. C. and Maslyn, J. M. (1998). Multidimensionality of leader-member exchange: An empirical assessment through scale development. Journal of Management, 24(1), 43-72.

Luthans, F. and Jensen, S. M. (2002). Hope: A new positive strength for human resource development. Human Resource Development Review, 1(3), 304322.

Luthans, F. and Youssef, C. M. (2004). Human, social, and now positive psychological capital management: Investing in people for competitive advantage. Organizational Dynamics, 33(2), 143-160.

Luthans, F. (2002). Positive organizational behavior: developing and managing psychological strengths. Academy of Management Executive, 16(1), 57-75.

Luthans, F., Avey, J. B., Avolio, B. J., Norman, S. M. and Combs, G. M. (2006). Psychological capital development: toward a micro-intervention brief introduction to psycap the input of hope development. Journal of Organizational Behaviour, 27, 387-393.

Luthans, F., Avolio, B. J., Avey, J. B. and Norman, S. M. (2007). Positive psychological capital: Measurement and relationship with performance and satisfaction. Personnel Psychology, 60(2007), 541-572.

Luthans, F., Luthans, K. W. and Luthans, B. C. (2004). Positive psychological capital: beyond human and social capital. Business Horizons, 47(1), 4550.

Luthans, F., Wyk, R. Van and Walumbwa, F. O. (2004). Recognition and development of hope for south african organizational leaders. Leadership \& Organization Development Journal, 25(6), 512-527.

Martin, H. J. and Shore, L. M. (1989). Job-satisfaction and organizational commitment in relation to work performance and turnover intentions. Human Relations, 42(7), 625-638. 
Martin, R., Thomas, G., Charles, K., Epitropaki, O. and McNamara, R. (2005). The role of leader-member exchanges in mediating the relationship between locus of control and work reactions. Journal of Occupational and Organizational Psychology, 78(1), 141-147.

Mobley, W. H., Horner, S. O. and Hollingsworth, A. T. (1978). An evaluation of precursors of hospital employee turnover. Journal of Applied Psychology, 63(4), 408-414.

Mobley, W.H. (1982). Employee turnover: Causes, consequences, and control. Addison-Wesley.

Nunnally, J. C. (1994). Psychometric theory. New York: McGraw-Hill.

Örücü, E. ve Özafşarlıŏlu, S. (2013). Örgütsel adaletin çalışanların işten ayrılma niyetine etkisi: Güney Afrika cumhuriyetinde bir uygulama. Mustafa Kemal Üniversitesi Sosyal Bilimler Enstitüsü Dergisi, 10(23), 335358.

Pajares, F. (2009). Toward a positive psychology of academic motivation: the role of self-efficacy beliefs. Handbook of positive psychology in schools. Routledge/Taylor \& Francis Group.

Poyraz, K. ve Kama, B. (2008). Algılanan iş güvencesinin, iş tatmini, örgütsel bağlllık ve işten ayrılma niyeti üzerindeki etkilerinin incelenmesi. Süleyman Demirel Üniversitesi İktisadi ve İdari Bilimler Fakültesi Dergisi, 13(2), 143-164.

Rızaoğlu, B. ve Ayyıldız, T. (2008). Konaklama işletmelerinde örgüt kültürü ve iş tatmini: Didim örneği. Anatolia: Turizm Araştırmaları Dergisi, 19(1), 720.

Sabuncuoğlu, E. T. (2007). Egitim, örgütsel bağlılık ve işten ayrılma niyeti arasındaki ilişkilerin incelenmesi. Ege Academic Review, 7(2), 613-628.

Sat, S. (2011). Örgütsel ve bireysel özellikler açısından iş doyumu ile tükenmişlik düzeyi arasındaki ilişki: Alanya' da banka çalışanlar üzerinde bir inceleme. Yüksek Lisans Tezi. Çukurova Üniversitesi SBE, Adana.

Scandura, T. A., Graen, G. B. and Novak, M. A. (1986). When managers decide not to decide autocratically: An investigation of leader-member exchange and decision influence. Journal of Applied Psychology, 71(4), 579-584.

Seligman, M. E. P. and Csikszentmihalyi, M. (2000). Positive psychology: An introduction. American Psychologist, 55(1), 5-14.

Seligman, M. E. P., Rashid, T. and Parks, A. C. (2006). Positive psychotherapy. American Psychologist, 61(8), 774-788. 
Sönmezer, M. G. (2007). Milli Ĕ̆itim Bakanlığı'nda çalışan öğretmenler ile Milli Eğitim Bakanlĭğ'ndan emeklilik veya istifa nedeniyle özel eğitim kurumlarında çalışanların iş tatmin düzeylerinin karşılaştırmalı analizi. Doktora Tezi. İstanbul Üniversitesi, SBE, İstanbul.

Sönmezer, M. G. ve Eryaman, M. Y. (2008). Kamu ve özel eğitim kurumlarında çalışan öğretmenlerin iş tatmin düzeylerinin karşılaştırılması. Ĕ̆itimde Kuram ve Uygulama, 4(2), 189-212.

Sparrowe, R. T. and Liden, R. C. (1997). Process and structure in leader- member exchange. Academy of Management Review, 22(2), 522-552.

Stajkovic, A. D. and Luthans, F. (1998). Self-efficacy and work-related performance: A meta-analysis. Psychological Bulletin, 142(2), 240-261.

Sunar, S. (2016). Örgütsel adaletin iş tatmini ve işten ayrlma niyeti üzerindeki etkisine yönelik bankacilik sektöründe bir uygulama. Yüksek Lisans Tezi. Bahçeşehir Üniversitesi, SBE, İstanbul.

Tabachnick, B. G. and Fidell, L. S. (2007). Using multivariate statistics. Boston: Pearson/Allyn \& Bacon.

Taşlıyan, M. (2007). Turizm ve seyahat sektöründe çalışanların iş tatmini ile müşterilerin memnuniyeti arasındaki ilişki: Kahramanmaraş'ta bir alan çalışması. Selçuk Üniversitesi Karaman İ.I.B.F. Dergisi, 12(9), 185195.

Tekin, V.N. (2009). SPSS uygulamal istatistik teknikleri. Ankara: Seçkin Yayıncilik.

Toker, B. (2007). Demografik değişkenlerin iş tatminine etkileri: İzmir'deki beş ve dört yıldızlı otellere yönelik bir uygulama. Doğuş Üniversitesi Dergisi, 8(1), 92-197.

Uyguç, N. ve Çımrın, D. (2004). DEÜ araştırma ve uygulama hastanesi merkez laboratuvarı çalışanlarının örgüte bağlılıklarını ve işten ayrılma niyetlerini etkileyen faktörler. D.E.Ü.İ.̇.B.F. Dergisi, 19(1), 91-99.

Ünlüsoy Dinçer, N. (2010). Hemşirelerin işyeri şiddetine maruz kalma durumları ile iş doyumları ve işten ayrilma eğilimleri. Doktora Tezi. Hacettepe Üniversitesi, SBE, Ankara.

Van de Schoot, R. and Miocević, M. (2020). Small sample size solutions: A guide for applied researchers and practitioners. Taylor \& Francis Group.

Vecchio, R. and Gobdel, B. (1984). The vertical-dyad linkage model of leadership: Problems and prospects. Organizational Behavior And Human Performance, 34, 5-21. 
Verma, J. P. and Verma, P. (2020). Determining Sample Size and Power in Research Studies. Springer, Singapore.

Walumbwa, F. O., Luthans, F., Avey, J. B. and Oke, A. (2011). Authentically leading groups: The mediating role of collective psychological capital and trust. Journal of Organizational Behavior, 32(1), 4-24.

Wasti, S. ve Önder, Ç. (2002). İş güvencesi endeksi ve iş güvencesi memnuniyeti ölçeği: Güvenirlik ve geçerlik analizi. Yönetim Araştırmaları Dergisi, 2(1), 23-47.

Werner, I. (1993). Liderlik ve yönetim. İstanbul: Rota Yayınları.

Wright, T. A. and Cropanzano, R. (1998). Emotional exhaustion as a predictor of job performance and voluntary turnover. Journal of Applied Psychology, 83(3), 486-493.

Youssef, C. M. and Luthans, F. F. (2009). An integrated model of psychological capital in the workplace. Oxford handbook of positive psychology and work. Oxford University Press.

Zhao, Z. and Hou, J. (2009). The study on psychological capital development of intrapreneurial team. International Journal of Psychological Studies, 1(2), 35-40.

\section{Kaynakça Bilgisi / Citation Information}

Büyükkaymakçı, Y. ve Sundu, M. (2021). Lider üye etkileşiminin iş tatmini ve işten ayrılma niyetine etkisinde psikolojik sermayenin düzenleyici rolü. OPUS- Uluslararası Toplum Araştırmaları Dergisi, 18(42), 5276-5313. DOI: 10.26466/opus.918842. 